\title{
Procesos de alteración asociados al contenido de minerales arcillosos en materiales pétreos
}

\author{
Role of clay constituents in stone decay processes
}

\author{
F.VENIALE ("); M.SETTI("); ${ }^{(* \text { C.RODRÍGUEZ-NAVARRO(") }}$,S.LODOLA ${ }^{(0)}$ \\ (")Dipartimento di Scienze della Terra. Univ. de Pavia (Italia), Lab. for Clay Research and Archaeometry \\ (“) The Getty Conservation Institute, Los Angeles (EE UU); Dep. de Mineralogía y Petrología. Univ. de Granada (España)
}

Fecha de recepción: 4-VI 2001

\section{RESUMEN}

Varios factores, tanto intrínsecos como extrínsecos, pueden condicionar la alterabilidad/durabilidad de materiales pétreos. Entre ellos, la presencia de minerales arcillosos, bien como constituyentes difusos o recubriendo-rellenando huecos, puede jugar un papel importante.

El resultado de la interacción de las particulas arcillosas y el agua ( $u$ otros fluidos) da lugar a patologias que son consecuencia de una serie de daños internos producidos por las continuas variaciones plásticas, asociadas a parámetros fisicos y cristaloquímicos de este tipo de minerales. Entre los que podemos citar la desestructuración de la piedra (bien por agregación-desagregación de las particulas arcillosas o por procesos de hinchamientocontracción) que está asociado, por ejemplo, con la cristalización de sales, producida por la transferencia de fluidos a su través, o a variaciones de humedad, a concentraciones iónicas de la solución, en función de la reactividad de las arcillas presentes, o a efectos provocados por tensiones osmóticas que modifican la geometria de aglutinación de las propias particulas.

En este artículo se analizan diferentes litotipos utilizados en la construcción y ornamentación de edificios históricos, todos ellos con minerales arcillosos, así como sus patologías, definiéndose las tendencias y los procesos degradativos encontrados.

\section{SUMMARY}

Stone alterability/durability is depending upon a number of intrinsic and extrinsic factors among which "clay minerals" constituents, either diffused throughout the stone framework or as coating-filling of void spaces, can play an important role.

Swelling-shrinking and aggregation-disaggregation phenomena occurring by interaction of argillaceous particles with water and other fluids can cause destructuration of the stone resulting in a variety of pathologies. Also salt crystallization which is depending on fluid transfer, moisture evaporation and ion concentration in the circulating solutions, can be influenced by clay mineral reactivity. Furthermore, saline solutions can drastically change the clay minerals behaviour, resulting in enhanced "osmotic" swelling and variations in clay aggregation geometry; these phenomena resulting in significant stone damage.

Case histories concerning several lithotypes used for monumental buildings and artistic manufacts are reported for showing the role of different clay mineral types in determining trend and intensity of decay processes.

\section{INTRODUCCIÓN}

La presencia de minerales arcillosos en diferentes litotipos utilizados como materiales de construcción puede deberse bien a los procesos de formación de

\section{INTRODUCTION}

Various lithotypes used as building materials can contain clay minerals as primary and/or secondary components. They can be detrital (sedimentary 
rocas sedimentarias, por alteraciones de fases durante la etapa hidrotermal-"deutérica" de cristalización magmática o a procesos de alteración meteórica de minerales primarios, como feldespatos, micas, anfiboles, piroxenos, olivinos $(1,2)$, dando lugar a nuevas fases minerales de carácter secundario (caolinita, illita, esmectita, sepiolita, etc.), con otra estructura cristaloquímica y, diferente morfologíadimensión de las partículas, que, obviamente, tienen un comportamiento distinto, sobre todo en presencia de agua, de componentes orgánicos e inorgánicos o soluciones electrolíticas, en función de su superficie y (re)actividad físico-química.

La existencia de estas arcillas, bien como constituyentes difusos o recubriendo-rellenando huecos, condicionan el desarrollo y morfología de los procesos degradativos $(3,4)$ ya que favorecen la descohesión, debido a la migración de fluidos, variaciones de humedad y volumétricas (expansiones y contracciones) de las arcillas $(5,6)$ o por procesos disruptivos de cristalización de sales (7-10).

Para el caso de las arcillas dentro de la red porosa y/o microfisural, cuando sometemos al material a ciclos de humectación-secado se modifican algunas de sus propiedades físicas, como es la capilaridad y la permeabilidad, ya que variamos el radio de acceso de poros de la red capilar (por la expansión-retracción producidas) lo que incide en el comportamiento de durabilidad de la roca. Evidentemente, la presión desarrollada vence la resistencia cohesiva de la roca, acelerando su degradación.

El estudio de una serie de litologías (areniscas, dolomías, calizas, "tuffeau", etc.) representativas en algunos monumentos históricos de Italia y Francia, así como algunas obras de arte de colecciones de museo, permite describir los procesos de degradación que aparecen y, a su vez, discutir el papel jugado por las arcillas en los procesos de alteración.

Además, evaluando cuantitativamente las diferentes fases arcillosas y su distribución espacial, podemos determinar, de forma precisa, el tipo de recursos y procedimientos a aplicar en la fase de restauración y preservación de los materiales.

\section{ARENISCAS DE LA BASÍLICA DE SAN MIGUEL DE PAVIA (ITALIA)}

Encontramos en esta catedral uno de los mejores ejemplos de arquitectura románica lombarda edificada en el N. de Italia. Su construcción data de la primera mitad del siglo XII (11). Los materiales utilizados en rocks), or originated by hydrothermal-deuteric and/ or weathering processes which had affected primary minerals as feldspars, micas, amphiboles, pyroxenes, olivines (1, 2). Clay mineral types (kaolinite, illite, smectite, sepiolite, etc.) have different crystalchemical structure and particle morphology; thus, depending on their surface and intracrystalline physico-chemical (re)activity, they behave in a different way when in contact with water, solution electrolytes and inorganic-organic compounds.

The presence of argillaceous particles, either diffused throughout the stone framework or as coating-filling of void spaces, can influence the appearance of decay forms and processes $(3,4)$. Fluid transfer, moisture evaporation, clay mineral expansion-shrinkage $(5,6)$ and salt crystallization (7-10) can provoke loss of cohesion, erosion, flaking, scaling and even spalling of the stone.

Clay particles located inside pores and/or microfissures, when swelling-shrinking as a consequence of wetting-drying cycles, can alter some physical properties, as permeability and capillarity, thus the stone alterability/durability. On the other hand, clay swelling pressure developed upon water/moisture intake, can overcome the tensile strength of the stone, leading to major damage.

Representative lithologies (sandstone, dolostone, limestone, "tuffeau", etc.) used in renowned historical monuments in Italy and France, as well as pieces of art from museum collections, and their decay processes are presented and discussed in order to evidence the role played by the different clay constituents in causing stone pathologies.

Moreover, a precise determination and quantitative evaluation of the various clay mineral phases, and their location in the context of the stone framework is also important for selecting means and procedures to clean, restore and preserve the stones.

\section{SANDSTONE OF THE BASILICA OF ST. MICHAEL IN PAVIA (ITALY)}

This admirable cathedral is one of the utmost example of romanesque architecture (lombard style) in northern Italy; its construction arises to first half of 12 th century (11). 
su estructura pétrea, esculturas y bajorelieves, que adornan la fachada (Fig. 1) son en arenisca amarillenta "dorada" (asimilable a la petrofacies grawáckica), extraída de la zona de Oltrepo, una región situada a unos $20 \mathrm{~km}$, hacia el S, de Pavía $(12,13)$.

Mineralógicamente está constituida por granos silíceos (predominantemente cuarzo) y, en menor porcentaje, feldespatos, micas, glauconita, anfiboles, epidotas, granates, magnetita y hematite, además de fragmentos de rocas (serpentinitas, micaesquistos, fillitas, cuarcitas y areniscas, con algunos restos fósiles como accesorios). Su granulometría, muy heterogénea, presenta un tamaño de grano medio $\leq 1 \mathrm{~mm}$.

La matriz, con una red porosa muy irregular, es un cemento micrítico, a veces con marga arcillosa (Fig. 2), teñida por granos de limonita ocrácea, finamente dispersos.
The structural stone blocks, sculptures and "basrelief" ornaments of the façade (Fig. 1) are entirely made up of a beautiful yellowish "golden" sandstone (greywacke petrofacies) exploited in the Oltrepo area, about $20 \mathrm{~km}$ southward of Pavia $(12,13)$.

Its composition is characterized by detrital mineral grains (mainly quartz and, in lesser amount, feldspars, micas, glauconite, amphibole, epidote, garnet, magnetite and hematite) and lithic fragments (serpentinite, micaschist, phyllite, quartzite and limestone; remnants of micro-fossils are subordinate) whose size is predominantly $\leq 1 \mathrm{~mm}$, but with some granulometric eterogeneity.

The matrix filling the irregular shaped pore-spaces is micritic calcite and/or a marly-clayey material (Fig. 2), pigmented by diffused very fine particles of ocraceous limonite.

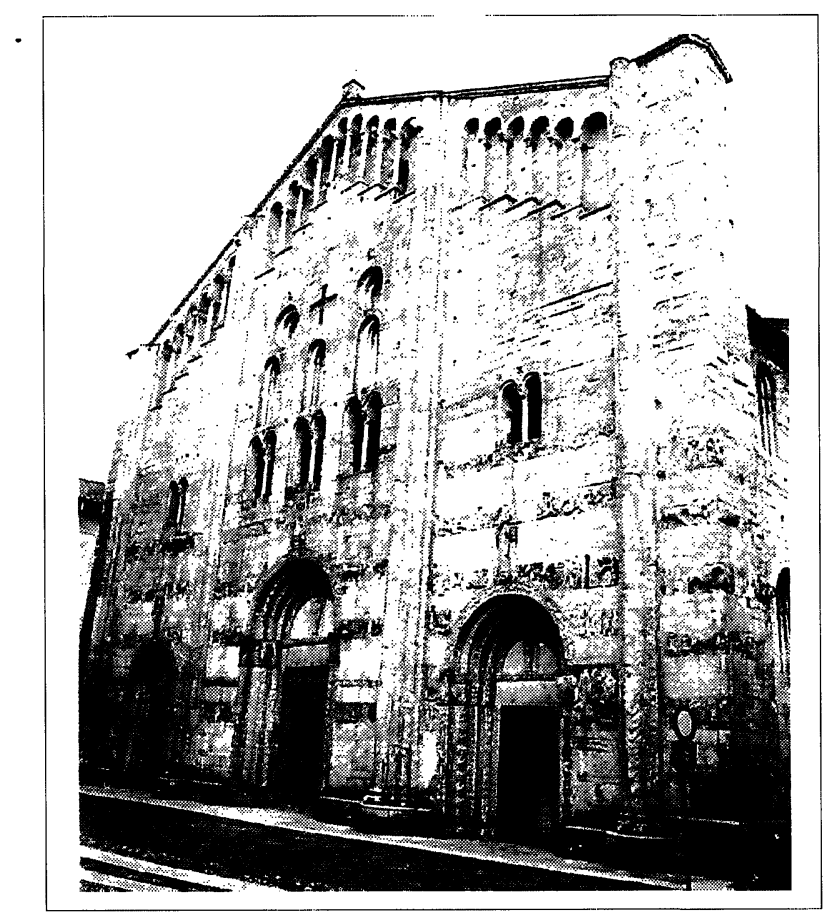

Figura 1.- Fachada de la catedral de San Miguel (Pavía, Italia).

Figure 1.- The façade of St. Michael cathedral (Pavia, Italy).

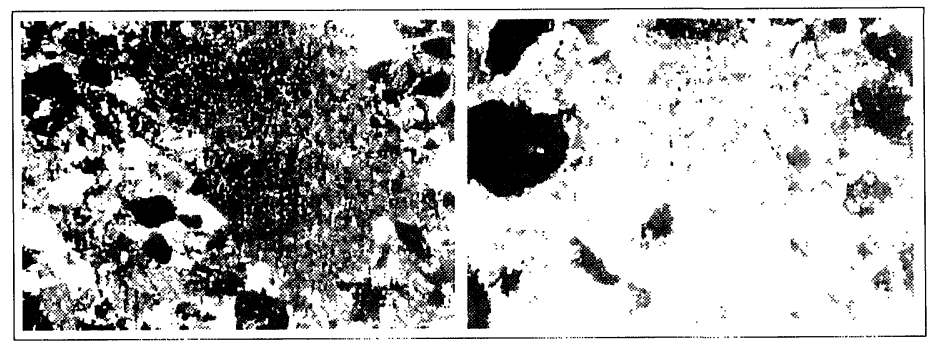

Figura 2.- Lámina delgada de la arenisca de la fachada de San Miguel, en Pavía,observada por microscopia óptica y en la que vemos diferentes aspectos de su cemento. Izquierda: marga arcillosa. Derecha: micrita calcítica.

Figure 2.- Thin section of the sandstone from the façade of St. Michael basilica in Pavia observed under the petrographic microscope; different aspects of the matrix. Left: marly-clayey. Right: micritic calcite. 
Las propiedades mecánicas, representadas en la Fig. 3, ponen de manifiesto el diferente comportamiento entre los materiales extraídos de las canteras y los de las fachadas, más afectadas por la contaminación y polución ambiental.

Los estudios realizados sobre la fachada (partiendo de fotografias tomadas de 1942 y 1965) evidencian una intensa degradación y erosión de este material, sobre todo en esculturas y bajorelieves, achacándose este fenómeno a la contaminación urbana (14). Investigaciones más recientes, llevadas a cabo entre 1985 y 1989, mediante técnicas microtopográficas $(15,16)$ confirman esta hipótesis, incluso en ese período tan corto de tiempo (Fig. 4), notándose que este fenómeno es más importante en aquellas zonas donde el cemento de la matriz es de naturaleza margosa.

Por otra parte, un tratamiento inadecuado, aplicado entre 1965-1967 $(17,18)$, y en contra de las recomendaciones técnicas que lo desaconsejaban (19), consistente en impregnar ("endurecimiento") por fluosilicatos de magnesio y cinc, produjo un desagradable cambio cromático (grisáceo), y -lo que es más grave- disolvió parcialmente el cemento micrítico carbonatado (20) apareciendo descohesiones en los granos (Fig. 5).

A partir de este hecho, se ha propuesto para su restauración (21) un seguimiento en el mantenimiento del proceso de conservación, realizándose limpieza superficial y tratamientos con agentes hidrorepulsivos, llegando -incluso- a sustituirse, eventualmente, algunas piezas de los bajorelieves y estatuas más afectadas.
Some mechanical parameters are reported in Fig. 3 showing the significant differences between quarry samples and materials exposed on the façade, that suffered weathering and pollution damage.

A photographic survey of the façade carried out in 1965 showed intense degradation and erosion of the sandstone, especially of the sculptured "bas-relieves", when compared with data referring to 1942; this is probably due to a damage related to urban atmospheric pollution (14). Further investigations performed in 1985 and 1989 by means of a microtopographic technique $(15,16)$ revealed a more intense erosion, still within such a short lapse of time (Fig. 4). Noteworthy, the erosion is deeper in those parts of the stone where the cementing matrix is of marly-clayey nature.

Moreover, an unsuitable treatment (impregnation "hardening" by $\mathrm{Mg}$-Zn-fluo-silicates) applied in 1965-67 (17, 18), despite such chemicals had been previously discredited (19), caused a disagreeable change in colour (to greyish), and dissolution of the micritic carbonate cement (20) with consequent decohesion of the sandy grains (Fig. 5).

Suitable interventions have been suggested for the restoration of the monument (21): continuous maintenance, surface cleaning and spraying with hydrorepulsive agents and, eventually, substitution of the deeply degraded "bas-relieves" and statues with newly sculptured elements.
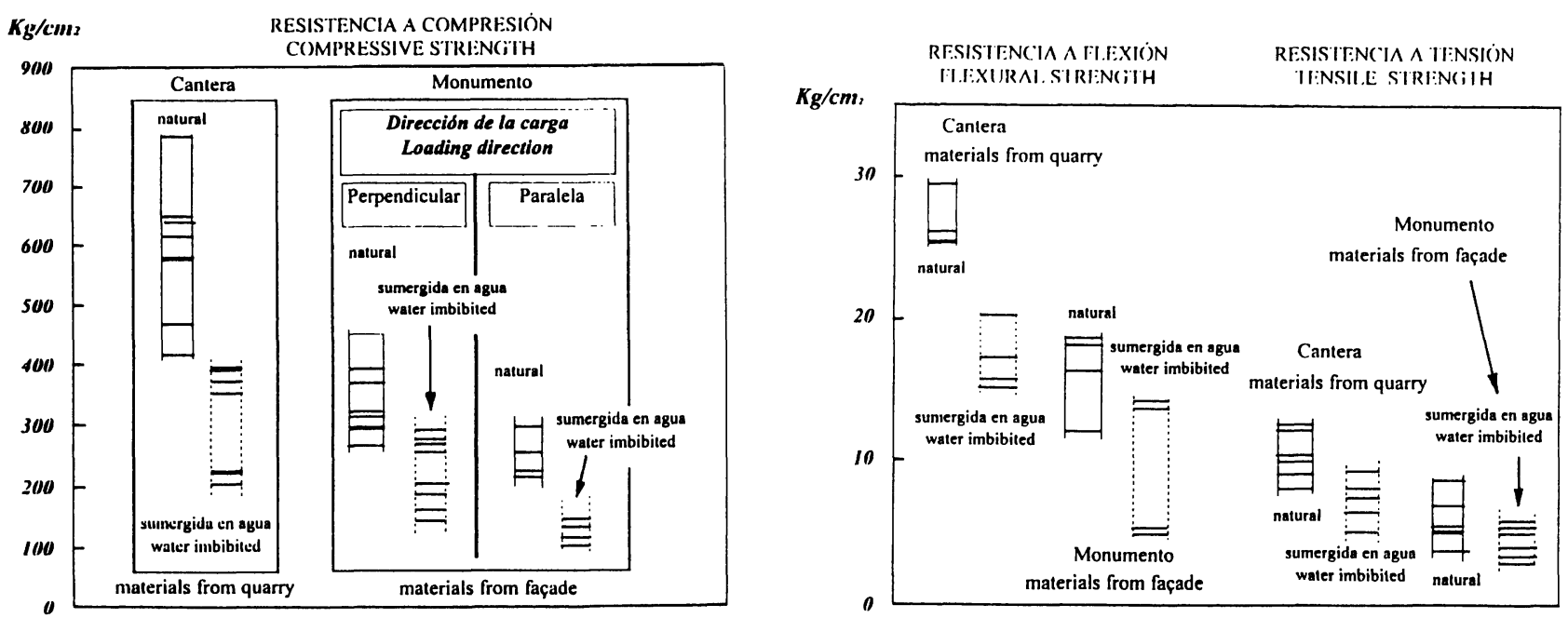

Figura 3.- Parámetros fisicos (resistencia del material) de la arenisca de la fachada de la basílica de San Miguel de Pavía. Obsérvense las diferencias entre las muestras tomadas en la cantera y las del monumento, así como la influencia de la impregnación con agua.

Figure 3.- Mechanical parameters of the sandstone from the façade of St. Michael basilica in Pavia. Notice the differences between quarry and monument samples, and the influence of water imbibition. 

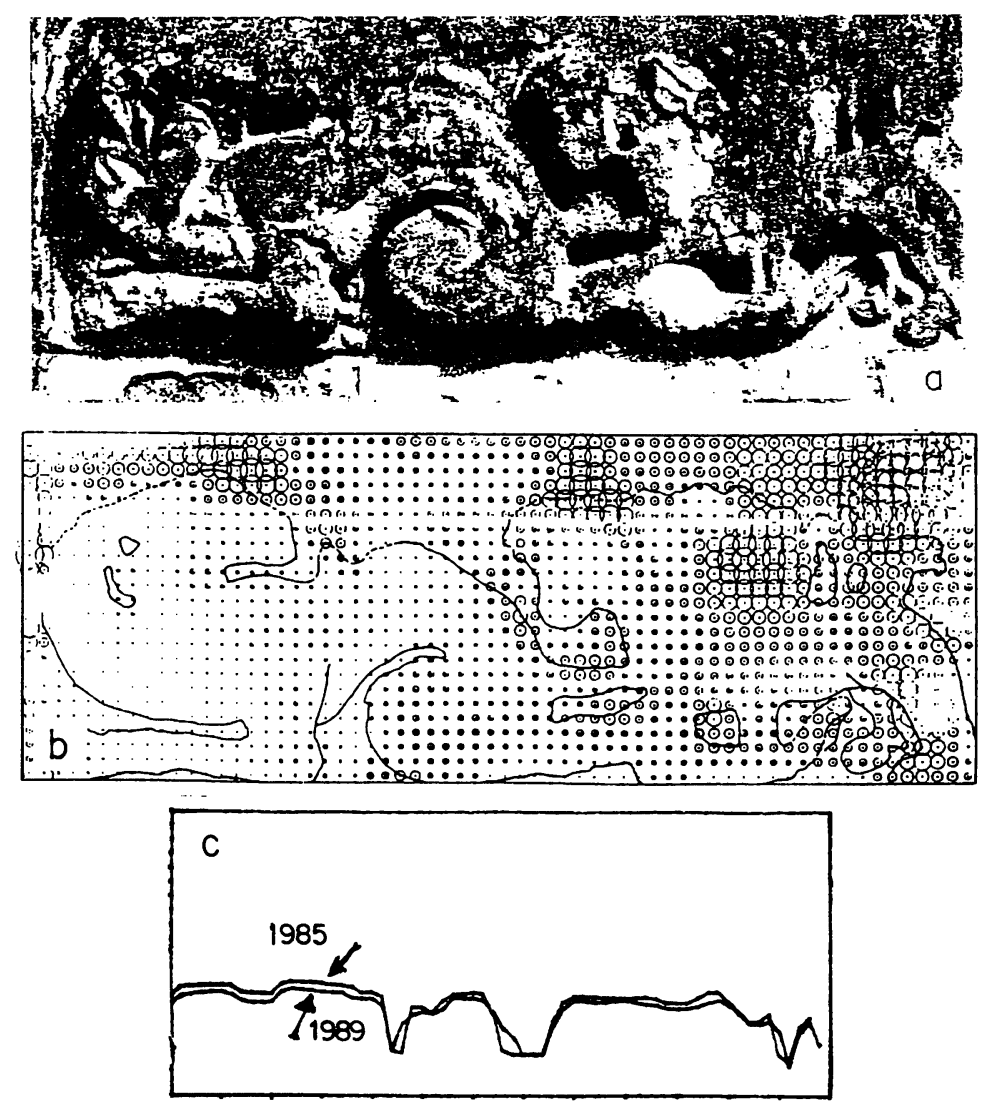

Figura 4.- Cartografiado microtopográfico de un bajorrelieve de la fachada de la basílica de San Miguel, en Pavía (a). El grado de erosión con respecto a 1985 y 1989 se evidencia por el tamaño del puntaje (b) y la sección del perfil (c).

Figure 4.- Microtopographic mapping of a "bas-relief" on the façade of St. Michael basilica in Pavia (a): The erosion degree referred to the 1985 and 1989 surveis is evidenced by spot-size (b) and by a section profile (c).
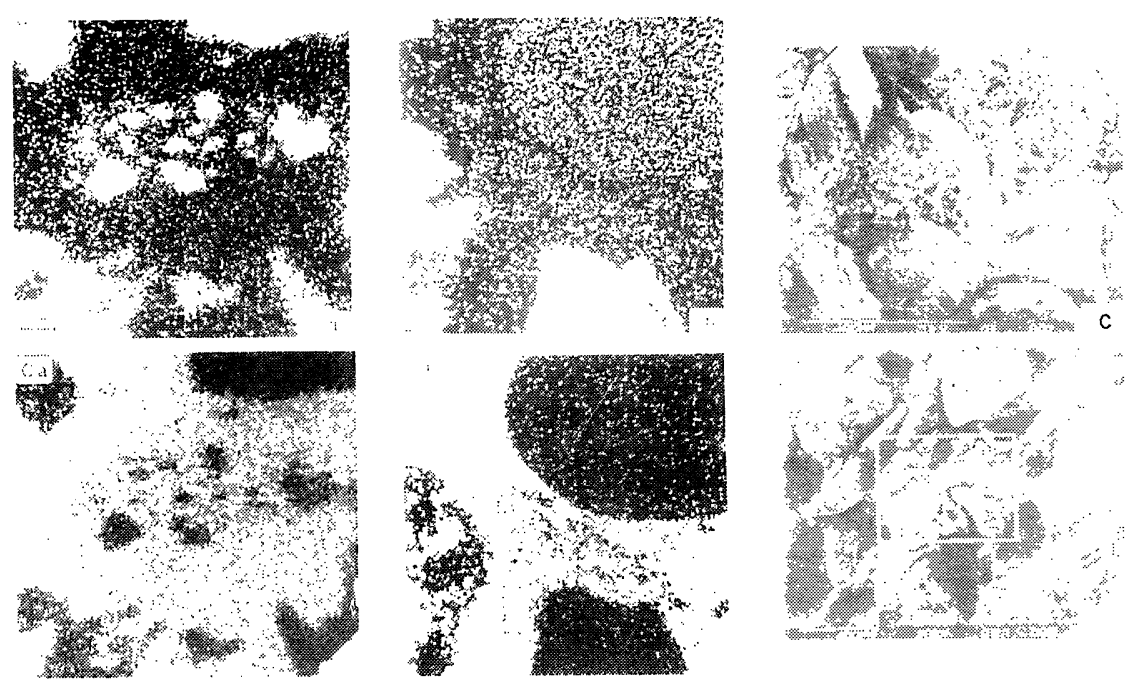

Figura 5.- Mapa de distribución del Ca y el Si en el cemento de la arenisca de la catedral de San Miguel, en Pavía, después del tratamiento con fluosilicato: obsérvese las pequeñas manchas (a) y la difusión (b) del $\mathrm{Si}$ dentro del cemento carbonático; (c) descohesión de los granos detríticos (abajo) debido a los procesos de disolución del cemento calcáreo, mostrando, en algunos casos, formas alveolares (fotografia superior).

Figura 5.- Si and Ca distribution maps in the matrix cement of the sandstone from St. Michael basilica in Pavia after treatment with fluo-silicates: notice the spots (a) and diffusion (b) of Si within the Ca-carbonate cement; (c) decohesion of detrital grains (below) due to dissolution of the calcite cement, in some instances showing "alveolar" aspect (above). 


\section{LA DOLOMÍA "PIEDRA DE ANGERA", LAGO MAGGIORE (NORTE DE ITALIA)}

Utilizada en algunos edificios históricos y monumentos de la región de Lombardía, al N. de Italia $(22,23)$ entre los que destacamos el interior de la basílica de San Miguel y la iglesia del monasterio de la Cartuja, a $7 \mathrm{~km}$ al N. de Pavía. Dentro de la misma ciudad hemos encontrado estos materiales en las balaustradas de los patios del edificio principal de la universidad (siglo XVIII) y las columnas que adornan el pórtico del monasterio de "San Felice" (siglo XV), ubicado en el casco antiguo.

La cantera, en la actualidad cerrada, está próxima a la villa de Angera, cerca de la terminación S. del lago Maggiore (24) y el río Ticino, su desaguadero, fue utilizado como vía de transporte.

De esta dolomía se han seleccionado tres variedades (blanca, amarilla y rosa) utilizadas con fines ornamentalles.

Los análisis mineralógicos, por difracción de rayos $\mathrm{X}$, nos diferencian tanto la naturaleza como la cantidad de los minerales arcillosos $(<5-10 \%)$ de las variedades rosa y amarilla, mientras que en la blanca no hay prácticamente arcillas. La distribución del tamaño de los poros, característica de cada variedad cromática, lo podemos asociar a la presencia de arcillas en la red porosa (Fig. 6)

\section{THE "PIETRA DI ANGERA" (DOLOSTONE) FROM LAKE MAGGIORE (NORTHERN ITALY)}

This stone has been used in many historical buildings and monuments of the Lombardy region (northern Italy) (22, 23). Among them, the inner architectural structure of the above mentioned basilica of St. Michael, and of the church of the Chartusian monastery located at about $7 \mathrm{~km}$ northward of Pavia town. Another extensive use has been made for the court balustrades of Pavia University Main Building (18th century), and the columns of the "portico" of monastery of St. Felice (15th century) located in the historical centre of Pavia town.

The quarry, now exhausted, is located near the village of Angera, close to the southern end of lake Maggiore (24), and the river emissary Ticino was the transportation waterway.

Three varieties of this dolostone have been selected for ornamental purposes on the basis of their different colour: white, yellow and pink.

$X$-ray diffraction analyses (Fig. 6) recognized different kinds and amount $(<5-10 \%)$ of clay minerals as constituents of the yellow and pink varieties, whereas the white one is practically free of clays. Pore-size distribution (Fig. 6) is different for the chromatic varieties, probably related to the clay particles location within the void spaces. Also the

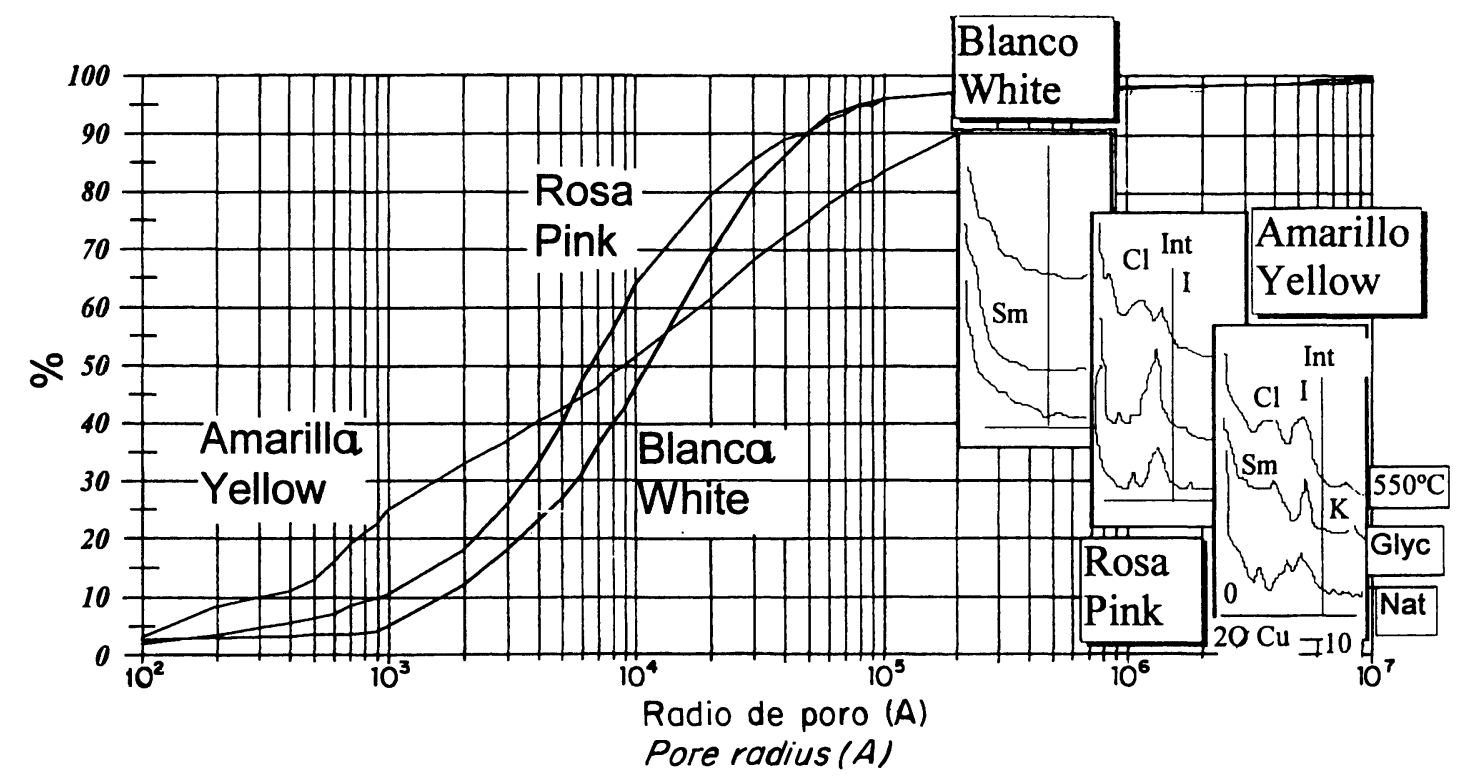

Figura 6.- Difractogramas de rayos $\mathrm{X}$ y curvas de porosimetría de las tres variedades de "Piedra de Angera". Obsérvense los tipos de minerales arcillosos presentes en las muestras amarilla y rosa, solamente. $\mathrm{Sm}=$ Esmectita; $\mathrm{Cl}=$ Clorita; $\mathrm{I}=$ Illita; Int = Interlaminados; $\mathrm{K}=\mathrm{Caolinita}$; Nat = muestra sin tratar; $\mathrm{Glyc}=$ muestra solvatada con etilenglicol; $550^{\circ} \mathrm{C}=$ muestra que ha sido sometida a tratamiento térmico durante dos horas.

Figure 6.- X-ray diffraction traces of the different-coloured varieties of"Pietra di Angera". Notice the different types of clay minerals present in the yellow and pink ones. Sm $=$ Smectite; $C l=$ Chlorite; $I=I l l i t e ;$ Int $=$ Intergrades; $K=$ Kaolinite; Nat $=$ natural specimen; Glyc $=$ ethylene-glycol solvatation; $550^{\circ} \mathrm{C}=$ heated 2 hours. 
Asimismo, las propiedades mecánicas (Fig.7) difieren sustancialmente, evidenciándose la importancia que las arcillas ejercen sobre estas propiedades, y que provocan una sustancial variación de la resistencia del material. En las Figs. 8 y 9 se ve la evolución de los procesos de alteración de los materiales de diferente color en la balaustrada del edificio universitario y las columnas del pórtico (25-28).

La alteración de la piedra es de carácter centrífugo (29), es decir, son descohesiones producidas a partir de un punto, donde se concentran las zonas de humedad, avanzando en forma de coronas o anillos, semejantes a microexfoliaciones. Este proceso, relacionado con la humedad atrapada, está asociado a minerales arcillosos con alta capacidad de retención de agua y que están expuestos a las condiciones ambientales (aparece en la balaustrada y en el pórtico), no produciéndose en las zonas más protegidas (escalinatas del edificio, pilares y bóvedas de la basílica de San Miguel y del monasterio). De esto colegimos que el factor predominante en el desarrollo de estas degradaciones son las condiciones ambientales y no el tiempo, ya que se ha podido demostrar la presencia de esta patología también en las nuevas balaustradas sustituidas

La eficiencia de los tratamientos de conservación aplicados (el "Istituto Centrale per il Restauro" ha recomendado una mezcla de etilsilicatos y alcoholoxi-xilanos, incluyendo, selectivamente, silicona protectora y una resina de poliuretano) ha sido probada en muestras de cantera, sin alterar, y en materiales alterados de los propios edificios $(30,31)$ constatándose una disminución de la absorción de agua con el tratamiento (esta capacidad de imbibición mechanical parameters (Fig. 7) differ significantly, indicating the influence of clay constituents, that reduce the stone strength. Details of the balustrade (Fig. 8) and of the "portico" columns (Fig. 9) show the decay aspects and degree of the different-coloured stone varieties $(25-28)$.

The stone shows a sort of "centrifugal" weathering (29), such a decay process is characterized by decohesion of humid spots, drying centrifugally and forming "corolla"-like micro-exfoliations. The process is correlated to moisture trapping, and the water retention is also influenced by clay mineral constituents. The decay degree is also depending on the exposure: it is mainly developed on the open-air court balustrades of University Main Building, less developed on the columns of St. Felice "portico", only incipient on the covered stairway of the University Main Building, and absent on the interior architectural elements (pillars, vaults) of St. Michele basilica and "Certosa" monastery church. Time does not seem to play a significant role in the decay evolution, because substituted balusters of the University Main Building show a decay degree almost similar to that of older ones.

The efficacy of the conservation treatments (suggested by the Italian "Istituto Centrale per il Restauro": admixture of ethyl-silicates and alchyl-oxy-xylanes, mixed or not with siliconic protective, and polyuretanic resin) has been tested for "fresh" quarry samples and for weathered samples from the buildings $(30,31)$ : the water absorption is reduced by the protective agents (the imbibition capacity is lower in the white variety),
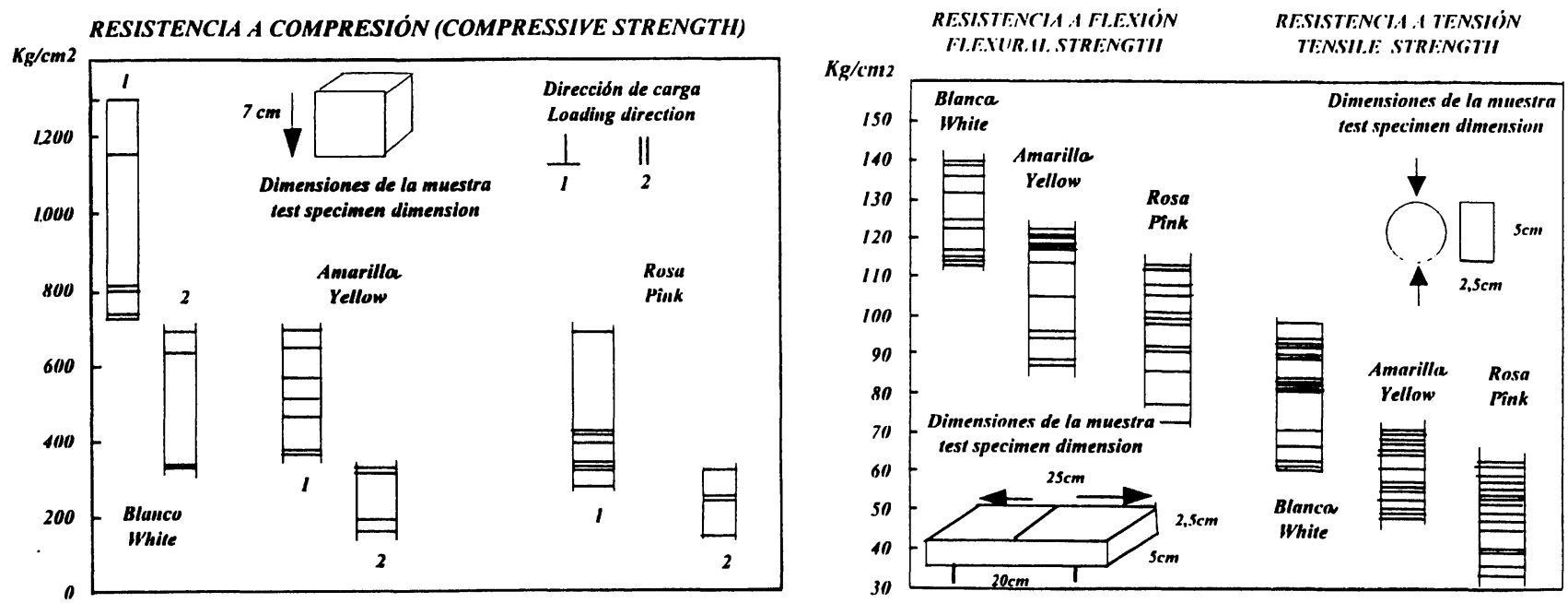

Figura 7.- Parámetros fisicos (resistencia) de las diferentes variedades de "Piedra de Angera".

Figure 7.- Physical parameters (resistance) of the different varieties of "Pietra di Angera". 

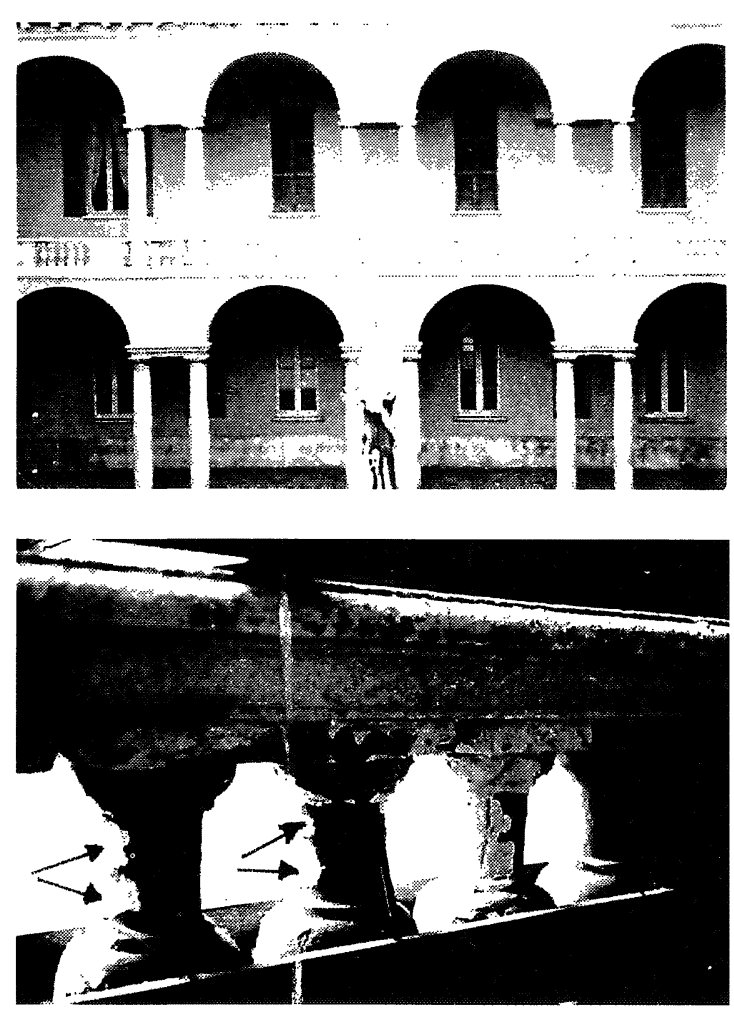

Figura 8.- Balaustrada del patio del edificio central de la Universidad de Pavia (la estatua representa a Alejandro Volta, inventor de la pila, que fue profesor de fisica de esta Universidad); obsérvense los diferentes grados de alteración de "Piedra de Angera"; véase también el punto de nucleación de los procesos centrífugos de alteración en la parte izquierda de la balaustrada (señalado por las flechas).

Figure 8.- Court balaustrade in the main building of Pavia University (the statue represents Alessandro Volta, the inventor of electrical battery/"pila", who was professor of physics at Pavia University); various decay degree of "Pietra di Angera"; notice the spot-centrifugal alteration on the left-side balausters (arrows).

es menor en la variedad blanca) debido a que el sistema poroso, sobre todo en el rango de la fracción capilar, se reduce, por colmatación y confinamiento, lo que hace bajar la capacidad de "transpiración", del material (32), aumentando, consecuentemente, la resistencia a la compresión (este parámetro da resultados distintos en las tres variedades ensayadas, siendo los valores, de menor a mayor, respectivamente, en la dolomía blanca-rosaamarilla).

Este tratamiento, a su vez, como mínimo, modifica la coloración del material.

\section{PIEDRAS ORNAMENTALES DE LA FACHADA DE LA IGLESIA DE LA CARTUJA (PAVÍA, ITALIA)}

Realizada la planta en 1396, se tardó más de dos siglos en construir y decorar esta "Certosa", lo que supuso una mezcla ordenada de estilos, desde el gótico, renacimiento, al barroco (33).
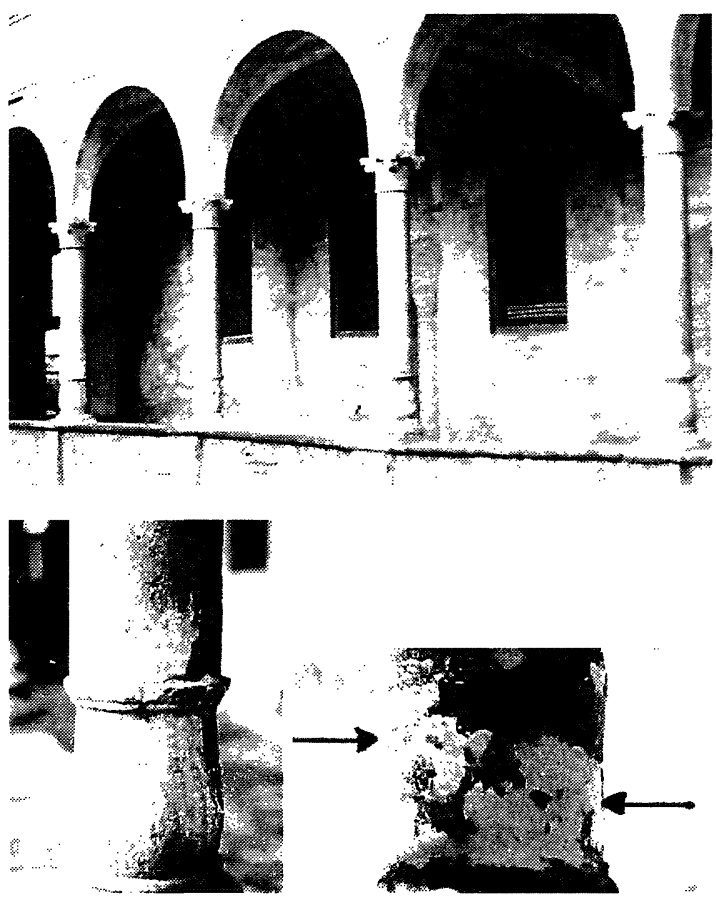

Figura 9.- Monasterio de "San Felice". Aparecen diferentes tipos de alteración en las columnas ejecutadas con las distintas variedades coloreadas de "Pietra di Angera": blanca (izquierda) y rosa (derecha). Véase el punto de alteración centrífugo de la variedad rosa (flechas).

Figure 9.- Monastery of St. Felice. Different decay degree of the columns made in different-coloured varieties of "Pietra di Angera": white (left) and pink (right). Notice the spot-centrifugal alteration on the surface of pink variety (arrows).

and compressive strength is increased; noteworthy, the latter parameter is different in the three chromatic varieties, i.e. respectively lower after the sequence white -pink- yellow. Furthermore, the pore system, especially capillary spaces, resulted partly filled and confined, thus reducing the stone capacity to "breath" (32).

Last but not least, the natural chromatic hue is modified by certain used chemicals.

\section{DECORATIVE STONES ON THE FAÇADE OF THE CHURCH OF CHARTUSIAN MONASTERY (PAVIA, ITALY)}

The foundations of this famous "Certosa" were laid in 1396, and it took more than two centuries to built and decorate the architectural complex; the result is a sequence of styles: gothic, renaissance, baroque (33). 
Su fachada, de color rosa y blanco (Fig.10), es de mármol de Candoglia, mientras que las estatuas que la adornan son de mármol blanco de Carrara. En su construcción, además, se han utilizado otros litotipos de diferente color (púrpura, verde, rojo, negro y gris) sobre todo en trabajos de decoración (34), destacando -entre ellos- la denominada "Piedra Simona" (una arenisca de la zona de Brescia, al N. de Italia) cuya composición es cuarzo y micas, en proporciones variables, cementados con una matriz arcillosa.

Su color característico es un rojo oscuro a violáceo, con una tonalidad más clara en las zonas donde predominan las láminas de mica y la matriz arcillosa (Fig. 11a). Su grado de conservación está relacionado con factores mineralógicos, granulométricos y texturales (34), apreciándose descohesiones superficiales en las facies más arenosas, y delaminaciones y descamaciones en las facies más finas (Fig. 11b). Los estudios por M.E.B. (Microscopía
The façade of the church (Fig. 10) is made of Candoglia marbles (pink and white), while the statues are of "Carrara" white variety. Other differently coloured (purple, green, red, black and grey) lithotypes were used for decorative works (34). Among them, the so-called "Pietra Simona" (a sandstone from Brescia territory, northern Italy) mainly composed of quartz and mica in variable ratio, with a clayey matrix.

The prevailing colour is dark reddish to violaceous, with lighter hues where mica lamellae and clayey matrix are prevailing (Fig. 11a). The state of conservation correlates well with variations in the stone mineralogical composition, granulometry and texture (34), superficial decohesion in the arenaceous facies, delamination and scaling in the silty one (Fig. 11b).

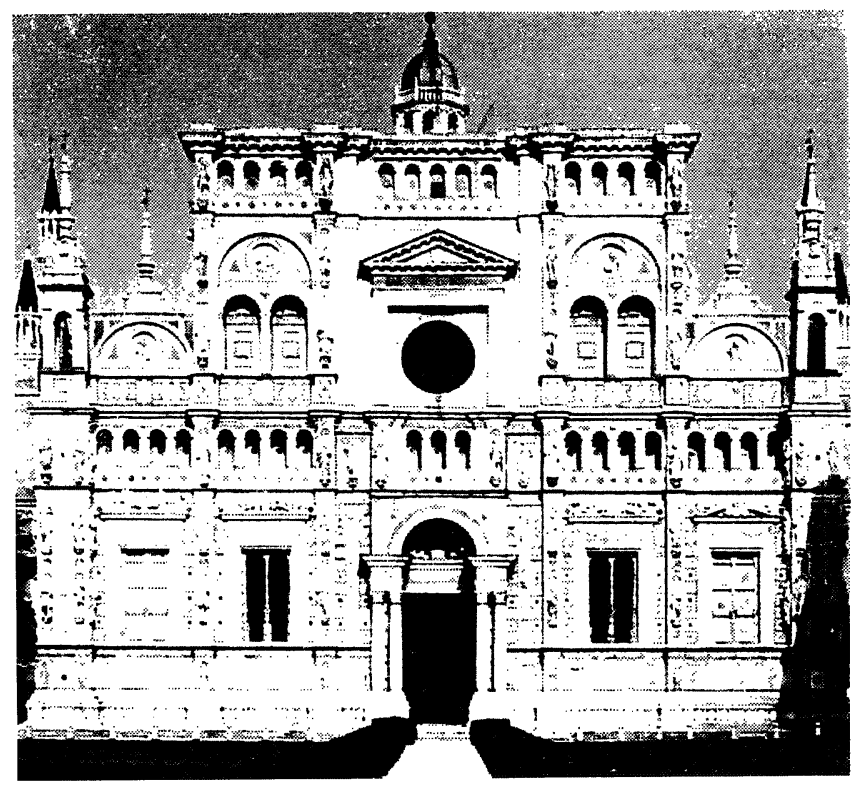

Figura 10.- Fachada de la iglesia del monasterio de la Cartuja ("Certosa" di Pavía).

Figure 10.- Façade of the church of Carthusian monastery ("Certosa" di Pavia).
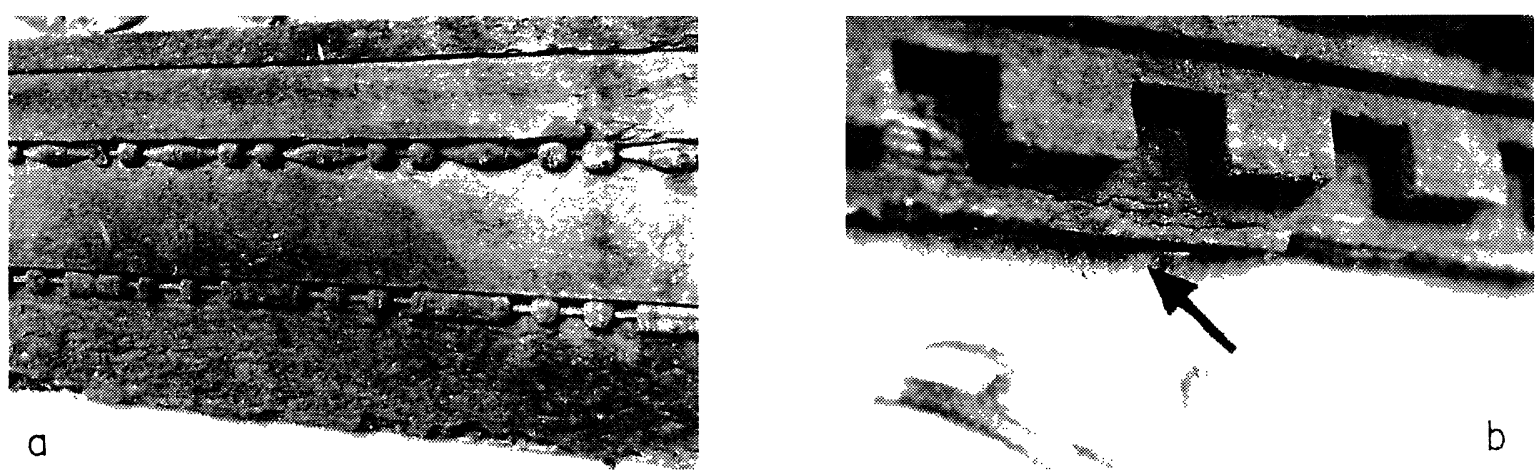

Figura 11.- (a) Facies policromática de "Piedra Simona"; (b) Facies siltosa de "Piedra Simona", donde apreciamos astillamientos subparalelos (flecha).

Figure 11.- (a) Varicoloured facies of "Pietra Simona"; (b) Silt facies of "Pietra Simona" with large subparallel scaling (arrow). 
Electrónica de Barrido) muestran la estructura hojosa subparalela de las micas, en la matriz de las muestras de canteras, (Fig. 12a), mientras que la del monumento tiene un aspecto desestructurado (Fig. 12b). Esto hace que su deterioro esté más avanzado debido a la mayor facilidad de penetración y difusividad del agua, agravándose posteriormente, debido a los procesos térmicos, estacionales o diarios, que sufre el monumento.

Otro material decorativo es la "Piedra de Oira", una serpentinita de color verdáceo oscuro, con vetas amarillentas de olivino. Su alteración pasa por un cambio cromático hacia el negro y marrón, respectivamente, además de generarse descohesiones y delaminaciones. Esto, que aún no se ha manifestado en las sustituciones hechas en las recientes intervenciones, hace pensar en un proceso lento. Los estudios mineralógicos, por difracción de rayos $\mathrm{X}$, detectan Mg-esmectita en las muestras alteradas (35), lo que permite explicar las tensiones disruptivas que aparecen en estas fases arcillosas que, con el agua, adquieren un comportamiento expansivo.

\section{EL “TUFFEAU” DE FRANCIA CENTRAL}

Material ampliamente extendido por la región del Loira, ha sido utilizado en la edificación de monumentos históricos (36-38). Su litotipo es una - roca calcárea margosa (creta) con importantes proporciones de cuarzo y micas. Se han distinguido dos petrofacies:

1. Blanca. De granulometría fina, presenta concreciones de cuarzo microcristalino (chert), además de constituyentes detríticos como el cuarzo, micas, fragmentos calcáreos fósiles (moluscos y foraminíferos), y como minerales accesorios tenemos turmalina, estaurolita y andalucita, además de nódulos de ópalo, glauconita y minerales arcillosos, entre las que hemos de citar esmectita, illita y caolinita, constituyendo la matriz.

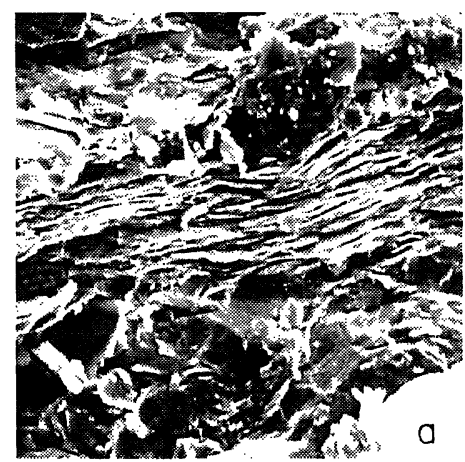

SEM observations (Fig. 12a) have shown thin subparallel micaceous beds in the matrix of quarry samples, whereas the same are interrupted and the "fabric" becomes destructurated (Fig. 12b) in damaged samples located on the monument. The latter condition makes the decay more intensive owing to an easier penetration and diffusion of water; the process could be further enhanced by daily and/or seasonal thermal changes.

Another decorative stone is the "Pietra di Oira", a serpentinite with prevaling dark-greenish colour (serpentine), and yellowish veinlets of olivine. The decay processes have changed the colours to blackish and brownish, respectively; furthermore, causing decohesion and detachment phenomena. Such decay aspects are not yet present in samples used for recent interventions to replace original damaged decorative elements. X-ray diffraction analyses allowed to detect $\mathrm{Mg}$-smectite as constituent of damaged samples (35). Noteworthy, smectites are clay minerals with swelling behaviour in presence of water, and the swelling pressure is a reason for stone destructuration.

\section{THE “TUFFEAU” FROM CENTRAL FRANCE}

The so-called "tuffeau" is a stone that was widely used in the Loira region for the construction of historical buildings (36-38). The lithotype is a variety of "chalky" limestone containing variable amount of detrital quartz and micas; two main petrofacies are distinguishable:

1) White. Fine-grained with cherty concretions. Besides the detrital constituents (mainly calcitic fossil fragments, quartz, micas and, subordinately, tourmaline, staurolite and andalusite) there are also opaline spherules, glauconite and other clay minerals (smectite, illite and kaolinite) constituting the matrix (the fossils remnants are mainly molluskes and foraminifera).

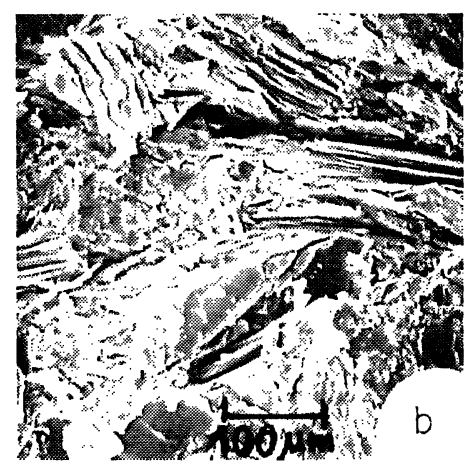

Figura 12.- Estructura del cemento arcilloso de "Piedra Simona": (a) muestra procedente de la cantera; (b) del monumento (imágenes de M. E. B.)

Figure 12.- Matrix "fabric" of "Pietra Simona": (a) sample for quarry; (b) sample for monument (SEM micrographs). 
El contenido total de carbonatos, incluyendo el cemento micrítico, oscila ente el 40 y el $70 \%$. Esta piedra, la más noble, se ha utilizado para la edificación de mansiones aristocráticas y castillos.

2. Amarilla. De granulometría gruesa, con un alto contenido en carbonatos $(\geq 70 \%)$ y glauconita. Su cemento es esparítico, pero en algunas zonas está ausente, lo que favorece el aumento de la porosidad, debido al incremento de su volumen total y tamaño de los huecos. Por estas características su uso se restringió bastante, aunque se encuentra, por ejemplo, en la catedral de Tours.

El estudio de la variedad blanca, por

M.E.B. (Microscopía Electrónica de Barrido), muestra una cementación micrítica (Fig. 13a) entre sus granos (restos fósiles y cuarzo) y nódulos opalinos (Fig. 13b) junto con las arcillas que presentan, a veces, rasgos de diagénesis (Fig. 13c). La exfoliación de las micas presenta interlaminaciones carbonatadas de microagregados (Fig. 13d).
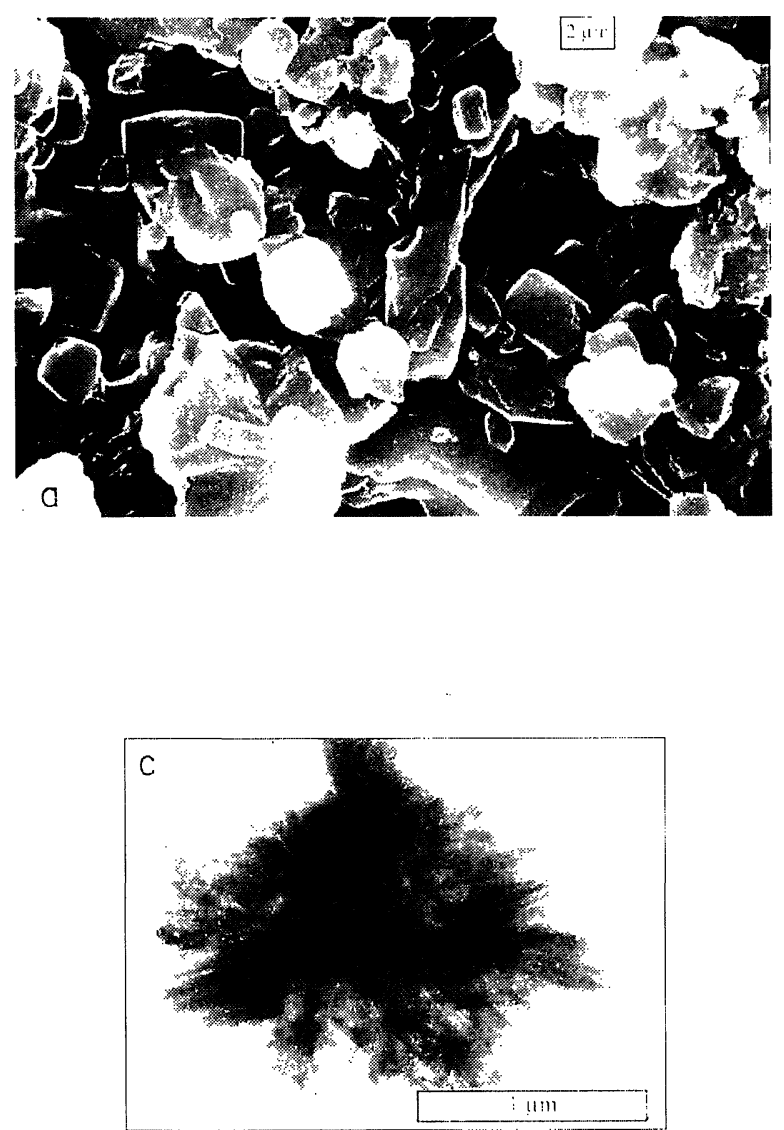

The whole carbonate content, including the "micritic" cement, is ranging from 40 to $70 \%$. This stone is the most "noble" and was used for the construction of castles and aristocratic houses.

2) Yellow. Coarser-grained, with higher carbonate $(\geq 70 \%)$ and glauconite contents. The calcite cements is "sparitic" and in some instances absent; the result is an increased porosity both as whole volume and void size. The stone was less used for important buildings, even though it is present in the cathedral of Tours.

Detailed observations of the white petrofacies under SEM (Scanning Electron Microscope) have shown that the coarse grains (fossil remnants and quartz) are connected by "micritic" calcite cement (Fig. 13a) and opaline spherules (Fig. 13b), together with clay minerals showing somewhat diagenetic features (Fig. 13c); isoriented mica lamellae can be interlayered with carbonate micro-aggregates (Fig. 13d).
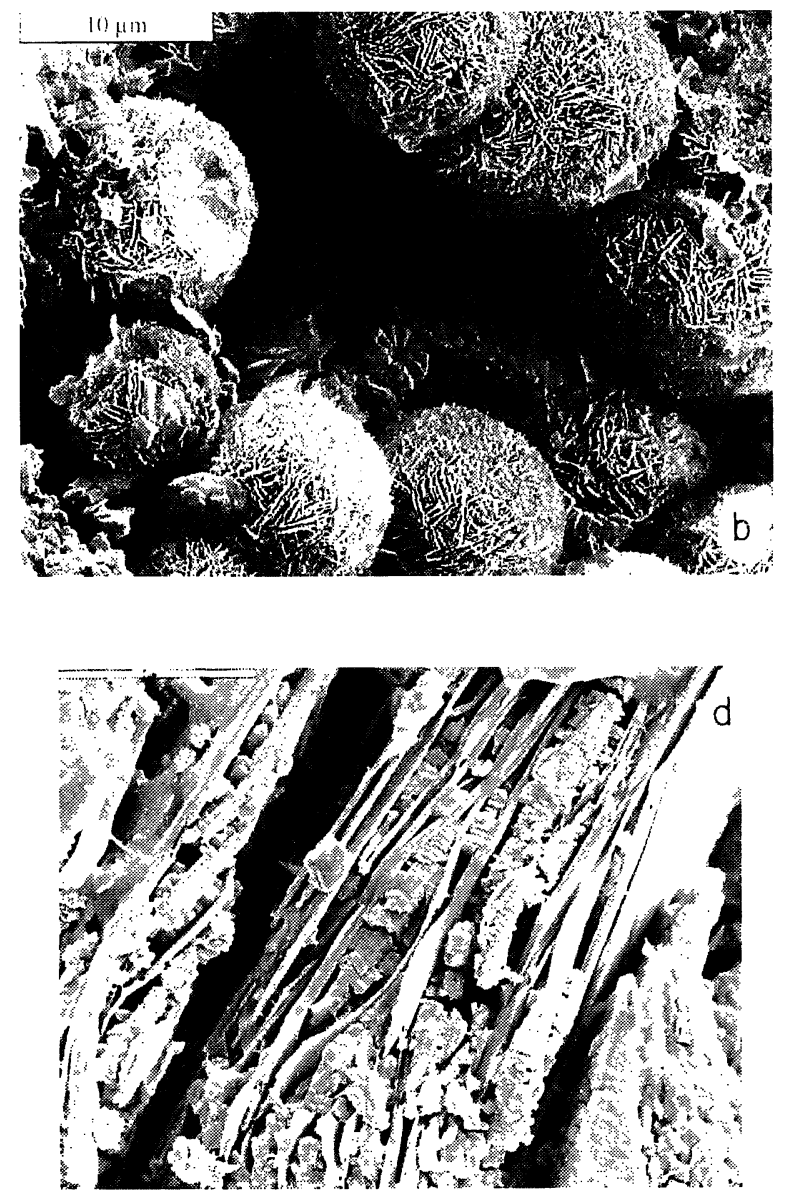

Figura 13.- (a) Cemento micrítico del "Tuffeau". (b) Esférulas opalinas y partículas arcillosas recubriendo espacios vacios. (c) Illita/smectita diagenética en forma de "agujas". (d) Láminas subparalelas de illita interlaminada por microagregados de carbonatos (M. E. B.).

Figure 13.- (a) Micrite calcite cement in "Tuffeau". (b) Opaline spherules and clay particles covering void spaces. (c) Details of diagenetic lath-shaped illite/smectite. (d) Subparallel illite lamellae interlayered by Ca-carbonate micro-aggregates (SEM). 
El análisis textural de estas muestras, por técnicas de procesado digital de imágenes, señala una serie de microfisuraciones (Fig. 14) que inducen a pensar que son materiales muy susceptibles de alterarse por su facilidad de impregnación de agua y su capacidad de difusión interna, lo que parece estar claramente relacionado con la presencia de minerales arcillosos.
Image processing of the "fabric" has evidenced a net of microfissures (Fig. 14), a threatening decay risk because of easier water impregnation and inner diffusion. This damage seems clearly connected with the presence of clay minerals.
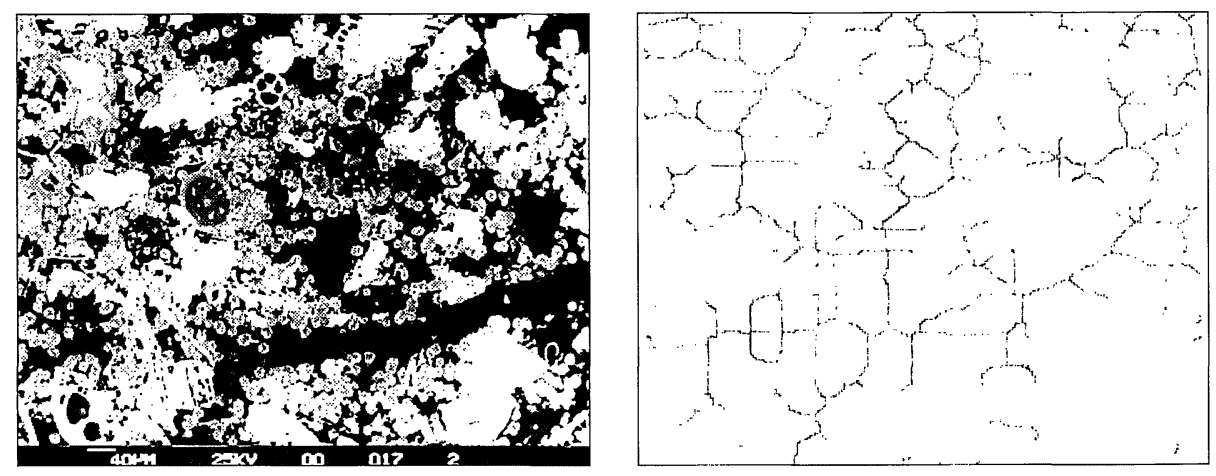

Figura 14.- Imagen de M. E. B. de la "fábrica" de un "tuffeau" alterado (izquierda); imagen procesada en la que se ve la red de microfisuración (derecha).

Figure 14.- (left) SEM picture of the "fabric" of a degraded "tuffeau"; (right) image processing showing the net of micro-fissures.

\section{PAPEL DE SEPIOLITA-PALIGORSKITA EN LA DEGRADACIÓN DE ESCULTURAS CALCÁREAS}

El continuo deterioro de una estela calcárea egipcia, de la segunda a la cuarta dinastía (2720-2150 a. C.), exhibida en el museo Phoebe Hearst (Berkeley, California) con desplacaciones en su superficie (39) y cuya patología era muy similar a las de otras esculturas, hechas con el mismo material calcáreo y almacenadas en diferentes museos (el Metropolitan de Arte de Nueva York y el Británico de Londres), indujo a pensar que este fenómeno no sólo estaba relacionado con la humedad relativa y cambios climáticos que se dan en el interior de los museos.

Experimentos de humectación-secado con agua destilada y humedad relativa cíclica desarrollaban una alteración, por microfisuración, similar a la desplacación vista en los ambientes del museo. Análisis termomecánicos confirmaban que el daño podría deberse al hinchamiento $(>4,5 \%)$ de las láminas subparalelas cuando la caliza se sumerge en agua. Se había pensado que el daño observado era debido a la cristalización ciclica de pequeñas cantidades de sales, por lo que, consecuentemente, tales esculturas habían sido tratadas y desaladas con apósitos acuosos, aunque el proceso no había sido eliminado.

Por otra parte, se analizó la mineralogía, especialmente el contenido en arcillas, que tendría un papel muy importante en la susceptibilidad de esa piedra a la alteración.

\section{ROLE OF SEPIOLITE-PALYGORSKITE IN THE DECAY OF LIMESTONE SCULPTURES}

Samples from an egyptian limestone stela dated II to IV dynasty (2720-2150 b. C.) from the Phoebe Hearst museum (Berkeley, California) exhibit an ongoing deterioration that is evidenced by continous delamination of the surface (39). It has been noted that many other sculptures carved from the same limestone and stored in different museums (Metropolitan Museum of Art-New York and British Museum-London) showed a complete loss of the carved surface relief while being subjected only to the relative humidity and temperature changes that occurred in the storage areas.

Wetting/drying experiments with distilled water and relative humidity cycling resulted in the same delamination cracking damage as that observed in the museum environments. Thermomechanical analyses confirmed that the damage was due to expansion (>4.5\%) parallel to bedding planes when the limestone was immersed in water. It was thought that most of the observed damage was due to cyclic crystallization of small quantities of salts, consequently, such sculptures had been treated and desalinated by aqueous poulticing, but the decay process was not arrested.

On the other hand, it was pointed out that mineralogy, especially the clay content, should play a role in the susceptibility of this stone to decay. 
Fue demuestrado (40) que el hinchamiento de los minerales arcillosos en esta caliza era el principal mecanismo responsable de los daños observados. Análisis petrográficos y mineralógicos ponen de manifiesto que una alta proporción de arcillas $(\geq 10 \%)$ se concentraban entre los planos de las láminas (Fig. 15); y que esta fracción arcillosa, en su mayor parte, era sepiolita (>90\%) y paligorskita $(<10 \%)$.
It was demonstrated (40) that the swelling of clay minerals contained in this limestone is the principal mechanism responsible for the observed damage. Mineralogical and petrographic analyses showed that a high proportion of clay constituents ( $\geq 10 \%)$ was concentrated along bedding planes (Fig. 15): the clay fraction mostly consists of sepiolite (>90\%) and palygorskite (<10\%).

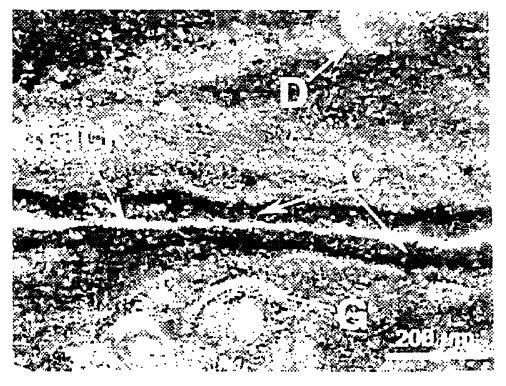

Figura 15.- Micrografia petrográfica de la caliza micrítica egipcia. Las capas se desarrollan por roturas asociadas a concentraciones de arcillas (C). Dolomita (D) romboédrica y bioclastos de globigerinas (G) asociados a la matriz de la caliza.

Figure 15.- Optical micrograph of the egyptian micritic limestone. Bedding planes are evident due to crack development where clays (C) are concentrated. Dolomite (D) rhombohedra and globigerina bioclast (G) are visible in the limestone matrix.

Por lo general, aunque no son expansivas, la sepiolita y la paligorskita pueden provocar daños importantes. La difracción de rayos $\mathrm{X}$ muestra que el hinchamiento "reticular" se detecta cuando las tratamos con etilenglicol y dimetil-sulfóxido.

El hinchamiento aparece también por la hidratación de las superficies arcillosas, asociado a las fuerzas electrostásticas entre las partículas de las arcillas (expansión osmótica) incluyendo el efecto de "doble capa difusa", presumiblemente originada por la presencia de concentraciones de $\mathrm{Na}^{+}$en la solución acuosa.

La expansión se ha observado directamente en un microscopio electrónico de barrido y de bajo vacío (ESEM) donde podemos realizar, a la vez, los ciclos de humectación-secado (Fig.16).

Para la conservación de estas esculturas se recomendó un estricto control de las condiciones ambientales en la sala (especialmente de una baja humedad relativa) y además se propuso que la extracción de sales utilizando agua o apósitos, aplicada durante mucho tiempo, se interrumpiera, ya que esto facilita el daño generado por el hinchamiento de las arcillas, que eran realmente las causantes de la alteración. Consecuentemente, los tratamientos convencionales, como el recubrimiento
Although normally non-expandable, clay minerals as sepiolite and palygorskite can promote significant damage. X-ray diffraction analyses showed that "crystalline" swelling of sepiolite occurred when in contact with ethylene-glycol and dimethyl-sulfoxide.

Swelling also occurred due to hydration of the clay surfaces, and to electrostatic forces between clay particles ("osmotic" swelling), involving the "diffused double layer", presumably promoted by the presence of $\mathrm{Na}$ counterions in the water solution.

The expansion due to swelling of the clays was directly observed at high magnification using an ESEM (environmental scanning electron microscope) when wetting/drying cycles were performed (Fig. 16).

For the conservation of these works of art, it was recommended that a strict environmental control (especially low relative humidity) should be imposed in museum storage rooms; furthermore, extraction of salts using water or poultices, which has been done as a routine procedure for years, should be discontinued since this promotes the damage generated by swelling of the clay constituents. Conventional treatments, using coatings such as 

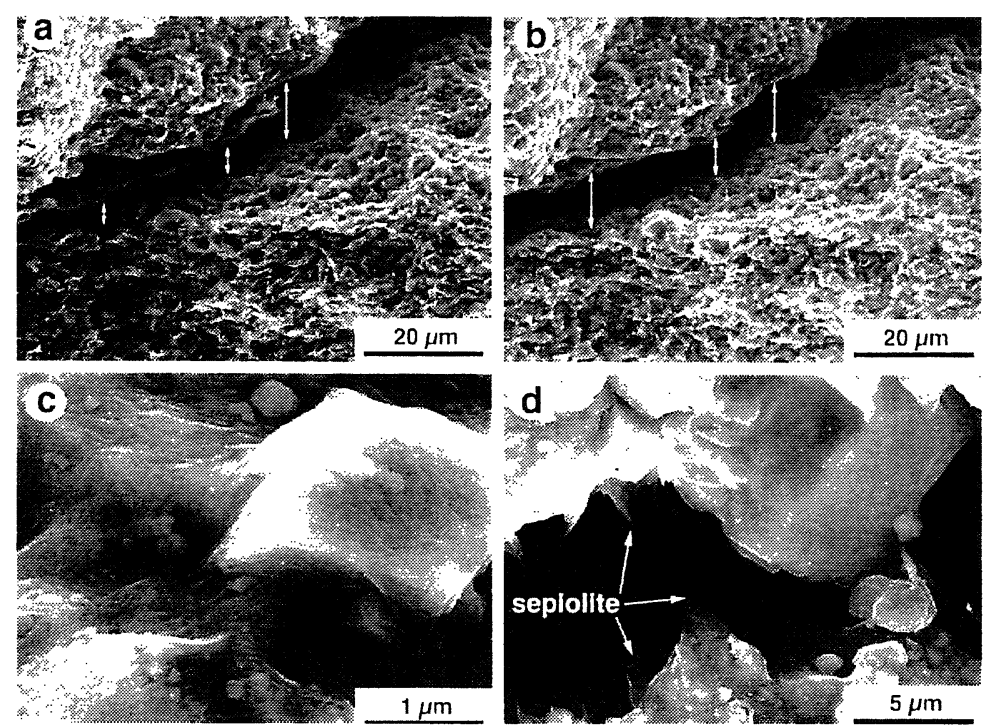

Figura 16.- Micrografia ESEM del proceso de desarrollo de fisuras en la caliza egipcia: (a) antes y (b) después de un ciclo de condensación/evaporación. Distribución de las arcillas en un poro (cubriendo un grano de calcita) y a lo largo de una fisura después de un ciclo de condensación/evaporación (c y d, respectivamente).

Figure 16.- ESEM micrograph of the process of crack development in the egyptian limestone stela: before (a) and after (b) a condensation/evaporation cycle. Clay distribution in a pore (covering a calcite grain), and along a crack after 1 condensation/evaporation cycle (c and d, respectively).

a base de ceras, no se han mostrado eficaces, por lo que, en la actualidad serían los tratamientos específicos, que eviten hinchamientos, los que deberian contemplarse para la protección de esculturas con esta problemática (por ejemplo, los tratamientos de surfactantes).

\section{CONCLUSIONES}

Las modernas técnicas de investigación en el campo de la degradación de los materiales de construcción en edificaciones de carácter histórico (41-45) consideran que las patologías desarrolladas tienen un origen tanto extrínseco como intrínseco $(46,47)$. Por ello, el comportamiento físico-mecánico de los materiales pétreos también dependerá de su situación dentro del edificio: cimentaciones, basamentos, elementos estructurales exteriores (columnas, paredes, arcos, bóvedas, etc.) o interiores (escaleras, etc.). Tales condiciones se establecen por la exposición de las piedras a los agentes de alteración (temperatura, humedad, lluvia, viento, polución, etc.) (48-51).

En ocasiones, el grado de alteración del material es una respuesta de las arcillas constituyentes al agua (superficie de exposición, penetración intersticial y flujo). La migración del agua (solución) por el interior de la piedra, sus condiciones de evaporación-flujoimbibición (especialmente la transferencia capilar) vienen determinadas por el tamaño y la forma de la red wax, have not been shown to be useful. New, unconventional treatments to avoid swelling should be considered for the protection of these sculpture (e.g. surfactants).

\section{CONCLUDING REMARKS}

Modern approaches to investigating the decay processes of stones used as building materials in historical architecture (41-45) take into account both intrinsic and extrinsic factors that can determine the appearing or development of decay forms $(46,47)$. The physico-mechanical behaviour of the stones is also depending on their position on the building: foundations, basement, structures in the open-air (as walls, columns, arches, vaults, cornices, etc.) or indoors (as inner staircase, etc.). Such conditions are determining the exposition of the stones to weathering agents (temperature, humidity, rain, wind, pollutants, etc.) (48-51).

In many instances, the state of stone decay is a response to the interaction between clay minerals and water (surface run-off, interstitial penetration and flux). Migration of water (solutions) through the stone, its imbibition-flux-evaporation conditions (especially capillary transfer) are influenced by the size-shape of pore-spaces (52). The porous network 
porosa (52), que, a su vez, depende de la distribución espacial de los granos minerales ("fábrica").

Los espacios vacíos, abiertos o cerrados, pueden ser los vínculos de acceso de la soluciones de agua al interior y, consecuentemente, su estado es el que controla la movilidad del fluido, sobre todo cuando el material está siendo sometido a ciclos alternantes de humectación-secado (53-58).

Si las arcillas se desarrollan en la red porosa, bien en forma de película o grumos que cieguen los conductos, la micro y macroporosidad se modifican por interrupción de estos conductos (porosidad confinada). $\mathrm{Si}$ la concentración electrolítica de las soluciones circulantes modifica la capacidad de cambio catiónico de las arcillas, asimismo, controlará los procesos de precipitación-disolución de las sales, produciendo tensiones internas entre los propios granos adyacentes, favoreciendo la descohesión del armazón estructural, y desagregando el material en formad de placas $(7,8,9$, $10,59,60)$.

Para conocer de una manera más precisa los procesos involucrados en el deterioro-conservación de las piedras necesitamos análisis detallados de la mineralogía, petrografía y textura-estructura de las partes dañadas, así como un registro de los productos de alteración $(61,62)$.

La distribución y porcentaje de las arcillas puede variar significativamente en los diferentes litotipos. La Fig. 17 muestra imágenes de T. C.. (Tomografía Computerizada) de una arenisca calcárea y un mármol blanco de Carrara, representando la distribución de las partículas arcillosas (63).

En realidad, el comportamiento hídrico (expansión-retracción) de las arcillas se explica por dos mecanismos: is depending on the spatial organization ("fabric") of mineral grains.

Open and/or sealed void spaces can make (or not) water solutions accessible, therefore their actual state is controlling the flow kinetic rate, especially when the stone is suffering alternating wettingt drying cycles (53-58).

The intergranular macro- and micro-porosity can be modified when occupied by film and/or cluster of argillaceous particles, which can also obliterate the interconnections between pores (confined porosity). Furthermore, the concentration of electrolytes in the circulating solutions can be determined by the cation exchange capacity of clay minerals, thus controlling the salt precipitation-dissolution; thus, internal tensions between the surrounding grains, that in turn cause decohesion of the wet stoneframe, can result in failing of grains and detachment of plaques $(7,8,9,10,59,60)$.

$A$ deeper understanding of the processes involved in the deterioration-conservation of stones needs detailed mineralogical, petrographic and structuraltextural analyses of the damaged parts, and precise records of the alteration by-products $(61,62)$.

The amount and distribution of clay minerals can vary significantly in different lithotypes. The Fig. 17 shows the Computerized Tomography (CT) images (63) of a calcareous sandstone and "Carrara" white marbles depicting the different distribution of clay particles.

Actually, the hydric behaviour (swelling/shrinking) of clay minerals is due to two different mechanisms:
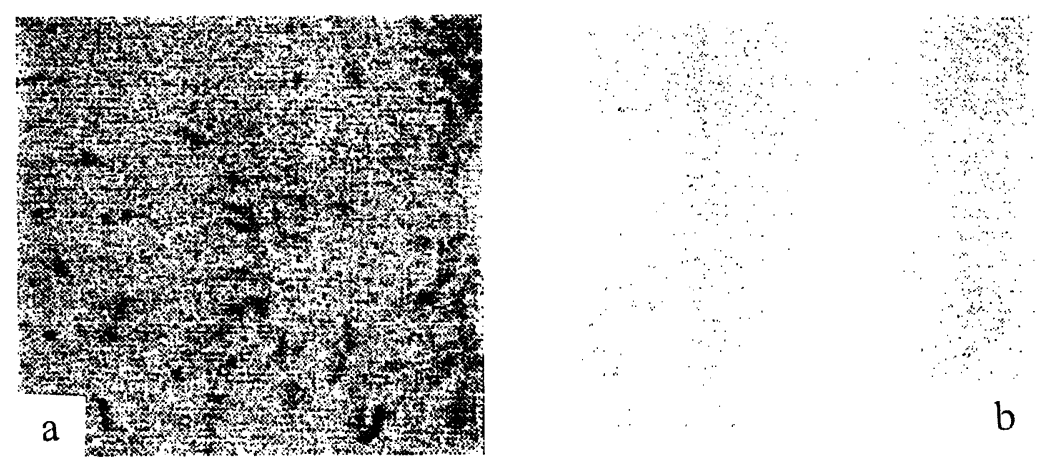

Figura 17.- Imágenes de T. C. de una arenisca calcárea (a) y del mármol de "Carrara" (b), mostrando los diferentes porcentajes y la distribución de los constituyentes arcillosos (gris oscuro).

Figure 17.- CT-images of calcareous sandstone (a), and "Carrara" marble (b), showing the different amount and distribution of clay constituents (blackgrey). 
(I) Expansión por proceso osmótico debida a las moléculas de agua (y electrolitos en solución) adsorbidas sobre la superficie externa de las partículas arcillosas ( "doble capa difusa") que es característica de cada especie de mineral arcilloso.

(II) Hinchamiento intracristalino, producido por la expansión interlaminar de la celda cristaloquímica (en especial para el caso de esmectitas) que puede sumarse a la presión osmótica $(6-64,67)$.

Algunos minerales arcillosos hinchables pueden expanderse debido a que admiten cantidades de agua que llegan a alcanzar 4-5 veces el volumen de la fase sólida. Adicionalmente, la imbibición de agua, en grandes cantidades, reduce significativamente la resistencia de la roca, favoreciendo el desmoronamiento del material, incluso para presiones disruptivas moderadas como la de las arcillas.

El resultado de estos importantes cambios de distribución espacial de las arcillas es, consecuentemente, un considerable daño de la estructura del material.

Cambios de humedad ( $y$ temperatura), estacionales y diarios, provocan expansiones-retracciones de los minerales arcillosos, con las consecuencias mecánicas de fatiga en el interior de las piedras, desarrollándose microfisuraciones y astillamientos en las zonas más superficiales. Por otra parte, una patología que suele desarrollarse por la concentracción de nódulos arcillosos es la erosión alveolar, pudiendo acelerarse y renovarse debido a los ciclos de humectación- secado.

Otro mecanismo frecuente, responsable de la degradación en los materiales, es la alteración inducida por procesos de hidrólisis de los minerales primarios (como es el caso de los feldespatos, micas, piroxenos, anfiboles, olivinos, etc.,) que pueden llegar a transformarse -progresivamente- en minerales arcillosos (1).

El esquema de la Fig. 18 representa los mecanismos de alteración en una arenisca, incluyendo la hidrólisis de las micas primarias.

La Fig. 19 señala la importancia de los procesos de cristalización de sales en la desagregación superficial $\mathrm{y}$ astillamiento de placas.

La metodología a establecer en futuros trabajos de conservación-restauración de edificios antiguos debería tener en cuenta las causas de los procesos de alteración de las rocas; es decir, hay un considerable número de factores que pueden afectar a la
(I) "Osmotic" swelling due to water molecules (and electrolytes in solution) adsorbed onto the external surface of the clay particles ("diffuse double layer"), which can occur in every kind of clay minerals;

(II) "Intra-crystalline" swelling due to the expansion of the interlayer space of the crystal-chemical units (peculiar for smectite, vermiculite, mixed-layers and "intergrades"), that can be added to the osmotic one (6-1

Some expandable clay minerals can intake water volume: even reaching 4-5 times the volume of the solid phase. Additionally, water impregnation strongly reduce the stone strength, thus facilitating the stone disintegration even for moderate clay swelling pressure.

This results in large changes of the spatial arrangement the clay particles and, consequently, in considerably damage to the stone structure.

Daily and seasonal changes in humidity (and temperatur can cause clay mineral swelling/shrinking with conseque. mechanical stresses inside of the stone, and formation of (micro)cracking and detachment of superficial stone flakt On the other hand, alveolar erosion may be produced by the presence of clay nodules. Such decay mechanisms can be exacerbated and renewed by continous wetting/drying cycles.

Another mechanism responsible for stone damage is the alteration induced by hydrolisis of some primary minerai constituents (as feldspars, micas, pyroxenes, amphiboles, olivines) which can be progressively transformed into cla minerals (1).

Schematic decay mechanisms are depicted in Fig. 18 for $\mathrm{C}$ sandstone where also hydrolisis of primary mica is involved.

The Fig. 19 shows the role of salt crystallization in the detachment of superficial plaques.

In future conservation-restoration works of ancient monuments will be essential to know the causes of the mechanisms damaging the stones. There are a number of 
durabilidad, por otro lado, agravar los mecanismos de degradación, tal y como se ilustra en la Tabla I. Podemos constatar que varios de ellos están relacionados con la presencia de las arcillas, provocando y acelerando los procesos de alteración.

Por otra parte, la aplicación de tratamientos químicos que proporcionen mejores resistencias a los elementos de construcción (32) puede modificarse en relación al tipo, cantidad y localización de los minerales arcillosos que tengamos en la roca.
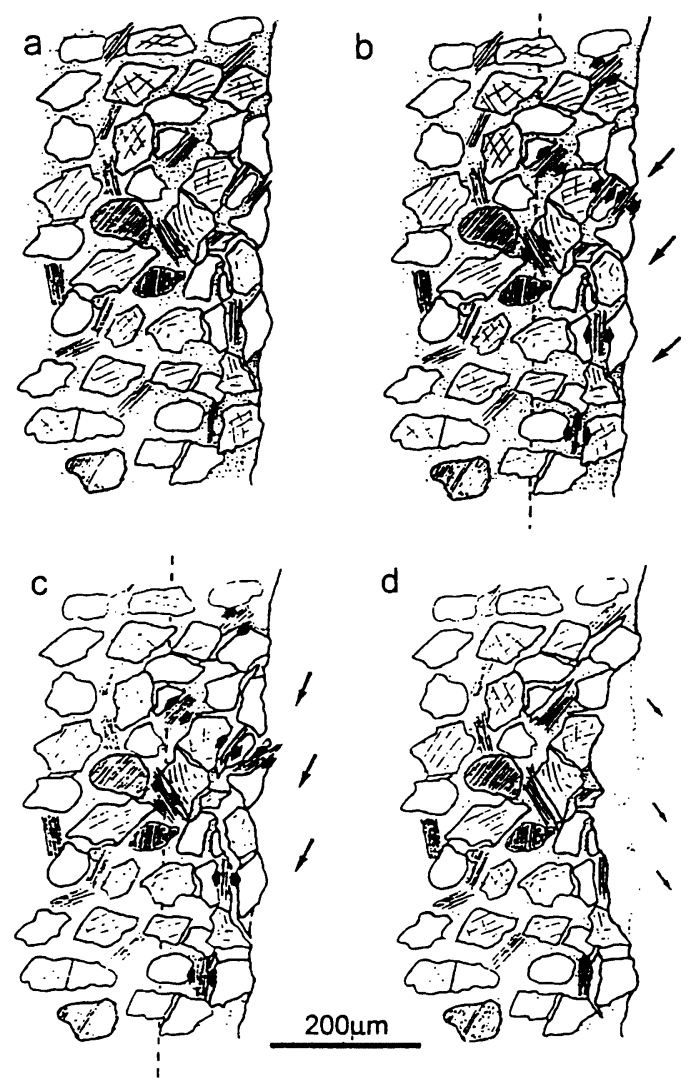

Figura 18.- Esquema en el que se representa el proceso de degradación de las areniscas: (a) sección de la roca sin alterar; (b) cuando el agua circula a través de la superficie se producen pequeñas infiltraciones que alcanzan cierta profundidad (marcada por la línea trazada) y se expande, conllevando a un despegue, por apertura de una fisura paralela a la superficie; (c) consecuentemente, los granos de mica se transforman, por hidrólisis, y se expanden entre los planos de esquistosidades, formándose clorita y esmectita dentro de su armazón estructural interlaminar; (d) el resultado es un rápido despegue de las placas y la rotura del los granos debido a disrupciones provocadas en la zona seca (68).

Figure 18.- Schematic diagram showing the decay processes in sandstone: (a) a section of the rock without any decay; (b) when water circulates through the surface, some part of the stone is wet to a certain depth (marked by a dashed line) and expands, leading to its detachment by opening a fissure system parallel to the surface; (c) furthermore, the mica grains suffer hydrolysis and also expand because of the crystallization of chlorite between the cleavage plane, and formation of smectite within the structural interspace; (d) the result is a rapid detachment of plaques and the falling of grains due to the internal tension caused in the wet zone (68). factors that can affect the durability (Table 1) and enhance the decay mechanisms. Several of them are due to the presence of clay minerals which can provoke and/or accelerate the degradation processes.

On the other hand, the performance of chemicals applied for improving the stone resistance (32) can vary depending on kind, amount and location of clay constituents.
A

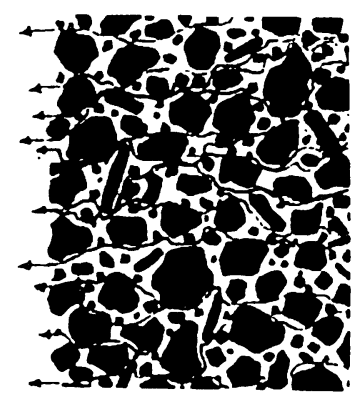

B
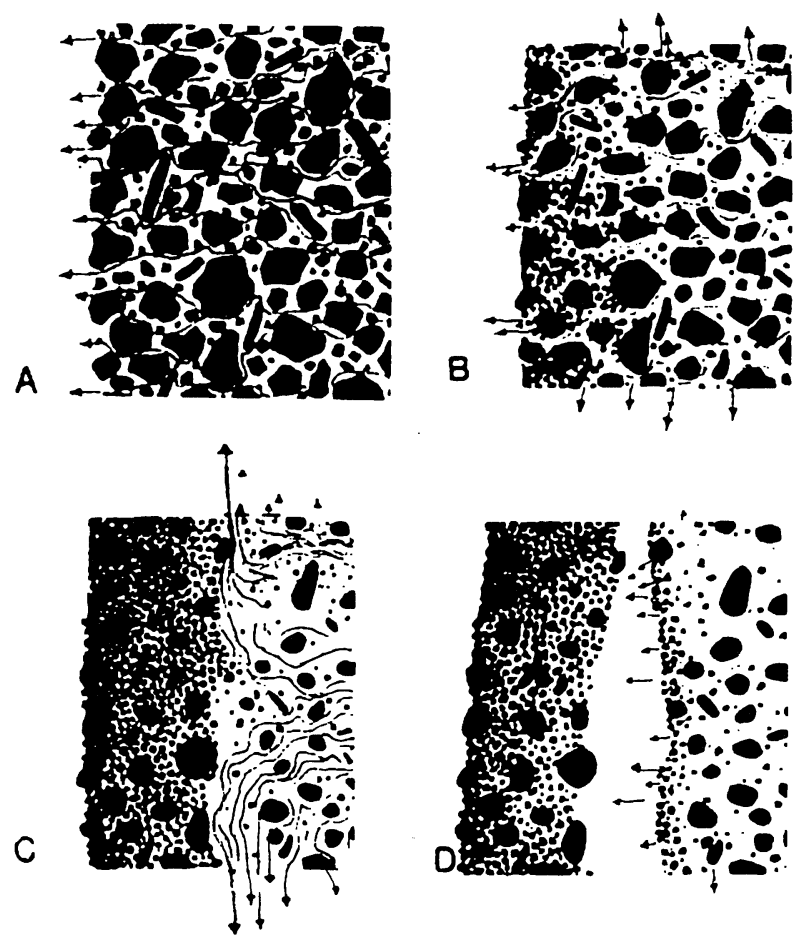

Figura 19.- Procesos de alteración superficial debido a cristalización de sales: (A) circulación de un fluido dentro de una roca sana; (B) cristalización de una sal por debajo de la superficie debido a los ciclos de humectaciónsecado; (C) fases cristalizadas que dificultan los procesos de imbibiciónpenetración-evaporación del agua y fluidos dañinos de otras fuentes (capilaridad-flujo) que se desplazan en otras direcciones; (D) disolución de fases cristalizadas produciendo fisuración y despegues en forma de placas (38).

Figure 19.- Superficial decay processes due to salt crystallization: (A) fluid circulation within a sound stone; (B) salt-calcite crystallization beneath the surface due to wetting/drying cycles; $(C)$ the crystallized phases hinder the water penetration-imbibition-evaporation and fluids rising from other ways (capillary flux) move through other directions; (D) dissolution of crystallized phases causes fissuration and detachment of flakes-plaques (38). 
Procesos de degradación en las rocas (de Kühnel 2000)

Driving forces of rock degradation (from Kühnel)

\begin{tabular}{|c|c|c|c|}
\hline $\begin{array}{l}\text { Producen variaciones de } \\
\text { Accompanied by changes of }\end{array}$ & \multicolumn{3}{|c|}{$\begin{array}{l}\text { Desmoronamiento intergranular provocado por procesos } \\
\text { Loosening of intergranular binding forces by processes }\end{array}$} \\
\hline , & $\begin{array}{c}\text { FISICOS } \\
\text { propiedades térmicas y } \\
\text { mecánicas } \\
\text { PHYSICAL } \\
\text { mechanical and } \\
\text { thermal properties }\end{array}$ & $\begin{array}{c}\text { QUTMICOS } \\
\text { reacciones entre } \\
\text { fases/transformaciones } \\
\text { CHEMICAL } \\
\text { phase } \\
\text { reactions/transformations }\end{array}$ & $\begin{array}{c}\text { BIOGÉNICOS } \\
\text { actividad antropogénica } \\
\text { BIOGENIC } \\
\text { anthropogenic activity }\end{array}$ \\
\hline Volúmen (Volume) & \multirow{5}{*}{$\begin{array}{l}\text { compresión (compression) } \\
\text { distensión (decompression) } \\
\text { enfriamiento (cooling) } \\
\text {.calentamiento (heating) } \\
\text { desagregación } \\
\text { (disintegration) y (and) } \\
\text { fragmentación } \\
\text { (fragmentation) }\end{array}$} & \multirow{5}{*}{$\begin{array}{l}\text { oxidación (oxidation) } \\
\text { reducción (reduction) } \\
\text { hidratación (hydration) } \\
\text { deshidrataión (deydration) } \\
\text { cristalización } \\
\text { (crystallisation) } \\
\text { disolución } \\
\text { (dissolution) }\end{array}$} & \multirow{5}{*}{$\begin{array}{l}\text { desarrollo (growth) } \\
\text { reducción } \\
\text { (decrease) } \\
\text { de la biomasa } \\
\text { (of biomass) } \\
\text { transformacion de la } \\
\text { biomasa } \\
\text { (transformation of } \\
\text { biomass) }\end{array}$} \\
\hline Área (Surface) & & & \\
\hline Masa (Mass) & & & \\
\hline Energía (Energy) & & & \\
\hline Propiedades (Properties) & & & \\
\hline
\end{tabular}

\section{BIBLIOGRAFÍA}

(1) Veniale, F. (1995): Minerali costituenti le rocce (pietre): processi e sequenze di lterazione. In "La pietra dei monumenti nel suo ambiente fisico". R.A. Lefevre(ed.), Scienze e Materiali del Patrimonio Culturale, Centro Universitario per i Beni Culturali, Ravello-Amalfi. Ist. Poligrafico dello Stato, 11-32.

(2) Zezza, U. (1995): Quarry-laboratory-monument as fundamental domains for stone conservation studies of the architectural heritage. Proc. 2nd Congr. "Rehabilitación del Patrimonio Arquitectonico y Edificación". Mar del Plata-Argentina, 227-231.

(3) Caner, E.N. \& Seeley, N.J. (1978): The clay minerals and the decay of limestone. Symp. UNESCO-RILEM "Deterioration and protection of stone monuments". Paris, 2, 34 pp.

(4) Kühnel, R.A., Van der Gaast, S.J., Brych, J., Laan, G.J. \& Kulnig, H. (1994): The role of clay minerals in durability of rocks. Appl. Clay Sci.,9,225-237.

(5) Dunn, J.R. \& Hudec, P.P. (1966): Water, clay and rock soundness. Ohio J. Sci., 66, 152-168.

(6) Prost, R., Koutic, T., Benchara, A. \& Huard, E. (1998): State and location of water adsorbed on clay minerals-Consequences of the hydration and swelling-shrinkage phenomena. Clays \& Clay Miner., 46, 117-131.

(7) Arnold, A., Kueng, A. \& Zehnder, K. (1985): Crystallization and habits of salt efflorescences on walls. Proc. 5th Int. Congr. "Deterioration and conservation of stone". Lausanne, 255-277.

(8) Arnold, A. (1995): Evolution des sals solubles dans l'altération et la conservation des monuments. In "La pietra dei monumenti nel suo ambiente fisico".R.A.Lefevre(ed.), Scienze e Materiali del Patrimonio Culturale, Centro Universitario peri Beni Culturali, RavelloAmalfi. Ist. Poligrafico dello Stato, 195-214.

(9) Zezza, F. (1995): Marine aerosol and stone decay. Sci. Total Env. 167, 123-143.

(10) Zezza, F. (ed.)(1996): Origin, mechanisms and effects of salts on the degradation of monuments in marine and continental environments. Proc. Workshop European Commission "Protection and Conservation of the European Cultural Heritage", Research Report no. 4.

(11) Peroni, A. (1967): San Michele di Pavia. Pavia Economica, 65 pp.

(12) Aguzzi, F., Fiumara, A., Peroni, A., Ponci, R., Riganti, V., Rossetti, R., Soggetti, F. \& Veniale, F. (1973): L'arenaria della basilica di S. Michele in Pavia. Atti Soc. Ital. Sci. Nat., 114, 401-464.

(13) Braga, G., Veniale,F. \& Zezza, U. (1986): La pietra del San Michele in Pavia. Atti Convegno "La pietra del San Michele in Pavia - Restauro e conservazione". Pavia, 83-94.

(14) Riganti, V., Perotti, A., Fiumara, A., Veniale, F. \& Zezza, U. (1981): Applicazioni di tecniche strumentali al controllo del egrado delle pietre nei monumenti: il caso della basilica di San Michele in Pavia. Atti Soc. Ital. Sci. Nat., 122, 109-138.

(15) Bezoari, G.(1987):Il degrado del S. Michele-Indagine microtopografica sulla consistenza del fenomeno. Pavia Economica, 3, $105-109$.

(16) Bezoari, G., Veniale, F. \& Zezza, U. (1988): La fotogrammetria come metodo di controllo non-distruttivo dello stato di degrado dei monumenti. Giomale Prove Non-distruttive, 3.

(17) Sanpaolesi, P.(1966a): Metodi di “indurimento" delle pietre dell'architettura. Vallecchi, Firenze.

(18) Sanpaolesi, P.(1966b): La facciata del S. Michele Maggiore. Bilancio tecnico dei lavori di trattamento con fluosilicati della facciata. Arte a Pavia-Salvataggi e restauri. Fusi, 11-45.

(19) Ferroni, E., Malaguzzi-Valeri, V. \& Rovida, G.F. (1969): Considerazioni sull'azione dei fluosilicati sul marmo. Atti Congr. “Conservazione delle sculture all'aperto". Bologna, 192-196(discussion p. 196-7). 
(20) Veniale, F. \& Zezza, U. (1987): New researches on the sandstone of St. Michael cathedral in Pavia. Atti Ticinensi Sci. Terra, 31, 253268.

(21) Zezza, U. (1986): Proposte operative di restauro del San Michele in Pavia. Atti Convegno "La pietra del San Michele in Pavia -Restauro e conservazione", Pavia, 131-139.

(22) Rodolico, F. (1953): Le pietre delle città d'Italia. Le Monnier, Firenze.

(23) Veniale, F., Zezza, U., Setti, M. \& Tortelli, M. (1987): Researches on decay, cleaning and conservation of stones and ceramic manufacts in historical buildings and monuments of Lombardy, northern Italy. 6th EUROCLAY, Sevilla, Round Table on "The decay of building stone, 53-55.

(24) Soggetti, F. \& Zezza, U. (1983): Coltivabilità e proprietà tecniche della "Pietra di Angera"(Lago Maggiore). Geol. Appl. \& Idrogeol., XVIII, 81-93.

(25) Cuzzolin, M. (1994): I prodotti di alterazione delle balaustrate in "Pietra di Angera" nel Palazzo Centrale della Università di Pavia. Tesi di Laurea, Univ. Pavia, 107 pp.

(26) Mangiagalli,M.G.(1978): Aspetti e cause della degradazione dei materiali litici del Palazzo Centrale dellaUniversità di Pavia e del chiostro di San Felice. Tesi di Laurea, Univ. Pavia, 163 pp.

(27) Riganti, V., Rossetti, R., Soggetti, F., Veniale, F. \& Zezza, U. (1978): Alterazione e protezione delle pietre dei monumenti storici dell'Università di Pavia. Atti Soc. Ital. Sci. Nat., 119, 85-109; see also: Decay and conservation of stone in historical buildings of the University of Pavia (Italy). Colloque Int. UNESCO-RILEM. Paris 1978, 7/20, 1-10.

(28) Zezza, U. (1977): Provenienza, tipologia petrografica e stato di conservazione delle pietre ornamentali utilizzate nei secoli XIV-XX per i monumenti e le lapidi del Palazzo Centrale dell'Università di Pavia. In: L. Erba e A. Morani "Monumenti e lapidi conservati nel Palazzo Centrale della Università di Pavia", Documenti sulla città di Pavia, Lions Club Pavia-Host, 225-232.

(29) Kieslinger, A. (1959): Rahmenverwitterung. Geol. \& Bauwesen, 24.

(30) Chiavarini, M., Guidetti,V.,Bortolaso,G. \&Zezza,U.(1994): Indagine sugli effetti protettivi dei poliuretani-fluorurati applicati su "Pietra di Lecce" (calcarenite). Proc. 3rd Int. Symp. "Conservation of monuments in the Mediterranean basin", Venezia, 897-902.

(31) Fiumara, A., Riganti, V., Veniale, F. \& Zezza, U. (1979): Sui trattamenti conservativi della "Pietra di Angera”. Geol. Appl. \& Idrogeol., XIV, 191-214.

(32) Coates, S. (1997): Chemists find ways to save monuments from pollution. New York Times-Science, November 18.

(33) AA.VV. (1988): La Certosa di Pavia - Passato e presente della facciata della chiesa. Monografia CNR, $319 \mathrm{pp}$.

(34) Massa, V., Venchiarutti, D., Zezza, U. \& Previde-Massara, E. (1989): Misure colorimetriche sul marmo di Candoglia e altre pietre utilizzate nella Certosa di Pavia. Atti $1^{\circ}$ Simp. "Conservazione dei monumenti nel bacino del Mediterraneo", Bari, 319-324.

(35)Alessandrini, G., Bugini, R., Dassu', G.,Ferrari, A., Peruzzi, R., Realini, M., Sorlini, C., Veniale, F.\&Zezza, U. (1986): The Pavia Certosa-Causes of decay of the church façade. Proc. Int. Symp. "Scientific methodologies applied to works of arts", Firenze 1984, 66-70 and 233-4.

(36) Boineau, M. (1996): Recommandations pour l'utilisation du "tuffeau" dans le batiment. Rapport CEBTP 94.061.

(37) Cautru, J.P. (1976): Le "tuffeau" de Touraine - Etude de son alteration. Mem. BRGM.

(38) Rautureau, M. (ed.) (2000): Tendre comme la pièrre: l'avenir du passé. Region Centre \& Université d'Orléans, 116 pp.

(39) Rodriguez-Navarro, C., Hansen, E., Sebastian-Pardo, E. \& Ginell, W.S. (1997): The role of clays in the decay of ancient egyptian limestone sculptures. J. Amer. Inst. Conservation, 36, 151-163.

(40) Rodríguez-Navarro, C., Sebastián-Pardo, E., Doehne, E. \& Ginell, W.S. (1998): The role of sepiolite-palygorskite in the decay of ancient Egyptian limestone sculptures. Clay \& Clay Miner., 46, 414-422.

(41) Baer, N.S. \& Snethlage, R. (eds.) (1997): Saving our architectural heritage - The conservation of historic stone structures. Dahlem Workshop Reports, Wiley, $425 \mathrm{pp}$.

(42) Calvi, G.P. \& Zezza, U. (eds.) (2000): Quarry-laboratory-monument. Proc. Int. Congr., Pavia, I, 585 pp.

(43) Smith, B.J., Whalley, W.B. \& Fassina, V. (1988): Elusive solution to monument decay. New Scientist, 49-53.

(44) Venice Charter, (1994): The conservation and restoration of monuments and sites. ICOMOS.

(45) Zezza, U. (1995): Le rocce dei monumenti-Composizione, proprietà, origini e impiego. In "Scienze e materiali del Patrimonio CulturaleIn "La pietra dei monumenti nel suo ambiente fisico". R.A. Lefêvre (ed.), Scienze e Materiali del Patrimonio Culturale, Centro Universitario per i Beni Culturali, Ravello-Amalfi. Ist. Poligrafico dello Stato, 33-64.

(46) Fitzner, B., Heinrichs, K. \& Kownatzki, R. (1995): Weathering forms-Classification and mapping. Denkmalpflege \& Naturstein Konservierung I, Ernst, 41-88.

(47) NORMAL, (1988): Alterazioni macroscopiche dei materiali lapidei-Lessico. CNR \& Istituto Centrale per il Restauro (Italy).

(48) Bell, F.G. (1992): The durability of sandstone as building stone, especially in urban environment. Bull. Ass. Eng. Geol., 29, 49-60. Discussion by E.M. Winkler p. 99-100, replay by F.G. Bell p. 101.

(49) Riganti, V., Specchiarello, M., Rossetti,R., Tortelli, M., Veniale,F.\&Zezza, U.(1993): Air pollution and microclimate influence on stone decay of monuments in urban and extra-urban area (Pavia, Lombardy region, northern Italy). Proc. Congr. RILEM-UNESCO "Conservation of stone materials". Paris, 196-203.

(50) Zezza, U., Previde-Massara, E., Massa, E. \& Venchiarutti, D. (1985): Effect of temperature on intergranular decohesion of marbles. Proc. 5th Int. Congr. "Deterioration and conservation of stones. Lausanne, 131-140.

(51) Zezza, U. \& Veniale,F.(1988): Ultrasonic investigations on quarry-and free-stones of historical monuments in Lombardy region, northern Italy. Proc. 6th Int. Congr. "Deterioration and conservation of stone". Torun-Poland, II, 303-312.

(52) Jeannette, D. (1997): Importance of the pore structure during the weathering processes of stones in monuments. In "Soils and sediments". Paquet H. \& Clauer N. (eds.), Springer, chapter 9, 177-190.

(53) Camuffo, D. (1995): Temperature, humidity, condensation and rainwater. In "La pietra dei monumenti nel suo ambiente fisico". R.A. Lefêvre(ed.), Scienze e Materiali del Patrimonio Culturale, Centro Universitario per i Beni Culturali, Ravello-Amalfi. Ist. Poligrafico delloStato, 113-127. 
(54) Camuffo, D. (1998): Microclimate for cultural heritage. Elsevier, $428 \mathrm{pp}$.

(55) Del Monte, M. \& Rossi, P. (1997): Fog and gypsum crystals in building materials. Atmosphere Env., 31, 1637-1646.

(56) Hawkins, A.B. \& McConnell, B.J. (1992): Sensitivity of sandstone strength and deformability to changes in moisture content. Q.

J. Env. Geol., 25, 115-130.

(57) West, G. (1994): Effect of suction on the strength of rock.. Q. J. Env. Geol., 27, 51-56.

(58) Zezza, U., Veniale, F., Zezza, F. \& Moggi, G. (1989): Effetti della imbibizione sul decadimento meccanico della "Pietra Leccese" (calcarenite). Atti $1^{\circ}$ Simp. "Conservazione dei monumenti nel bacino del Mediterraneo", Bari, 263-269.

(59) McGreevy, J.P. \& Smith, B.J. (1984): The possible role of clay minerals in salt weathering. Catena, 11, 169-175.

(60) Warke, P.A. \& Smith, B.J. (2000): Salt distribution in clay-rich weathered sandstone. Earth Surf. Processes \& Landforms, 25, 13331342.

(61) Veniale, F. \& Zezza U.(eds.)(1986): Advanced methods and techniques for the study of stone decay, cleaning and conservation. Proc. Workshop CEE-ICOMOS Group Petrography, Pavia, 158 pp.

(62) Veniale,F.\&Zezza, U.(eds.)(1990): Advanced analytical methodologies for the investigation of damaged stones. Proc. Workshop CEE, Pavia.

(63) Jacobs, P., Sevens, E. \& Kunnen, M. (1995): Principles of computerised X-ray tomography and applications to building materials. Sci Total Env., 167, 161-170.

(64) Baudracco, J. \& Tardy, Y. (1988): Notions concerning the double ionic layer. In "Dispersion and flocculation of clays in unconsolidated sand reservoir subjected to percolation with $\mathrm{NaCl}$ and $\mathrm{CaCl}{ }_{2}$ solutions at different temperatures". Appl. Clay Sci., 3,347-360. (65) Farmer, V.C. (1978): Water on clay particle surface. In: “The chemistry of soil constituents”, J.D. Greenland \& M.H.B. Hayes (eds.), Wiley, 405-448.

(66) Low, P.F. (1987): The clay-water interface. Proc. Int. Clay Conf. AIPEA - Denver 1985, 247-256.

(67) Newman, A.C.D. (1987): The interaction of water with clay minerals. In "Chemistry of clays and clay minerals". Wiley, 237274.

(68) Valls del Barrio, S., García Vallés, M.\& Vendrell-Saz, M.(2000): Mineralogical decay processes in stones: the case of the Lleida Cathedral. Eur. J. Miner., 12, 651-659.

\section{Nota de la Redacción}

El Comité de Redacción agradece a D. Nicanor Prendes la traducción al español y la revisión técnica del manuscrito. 